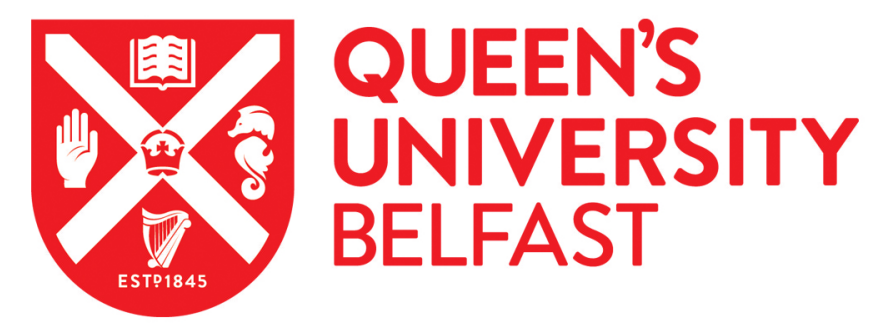

\title{
Understanding catalytic reactions over zeolites: A density functional theory study of selective catalytic reduction of NOX by NH3 over Cu- SAPO-34
}

Mao, Y., Wang, Z., Wang, H-F., \& Hu, P. (2016). Understanding catalytic reactions over zeolites: A density functional theory study of selective catalytic reduction of NOX by NH3 over Cu-SAPO-34. ACS Catalysis. https://doi.org/10.1021/acscatal.6b01449

Published in:

ACS Catalysis

Document Version:

Peer reviewed version

Queen's University Belfast - Research Portal:

Link to publication record in Queen's University Belfast Research Portal

Publisher rights

This document is the Accepted Manuscript version of a Published Work that appeared in final form in ACS Catalysis, copyright $\odot 2016$ American Chemical Society after peer review and technical editing by the publisher. To access the final edited and published work see http://pubs.acs.org/doi/abs/10.1021/acscatal.6b01449

\section{General rights}

Copyright for the publications made accessible via the Queen's University Belfast Research Portal is retained by the author(s) and / or other copyright owners and it is a condition of accessing these publications that users recognise and abide by the legal requirements associated with these rights.

Take down policy

The Research Portal is Queen's institutional repository that provides access to Queen's research output. Every effort has been made to ensure that content in the Research Portal does not infringe any person's rights, or applicable UK laws. If you discover content in the Research Portal that you believe breaches copyright or violates any law, please contact openaccess@qub.ac.uk. 


\title{
Article
}

Subscriber access provided by QUEENS UNIV BELFAST

Understanding catalytic reactions over zeolites: A density functional theory study of selective catalytic reduction of NOX by NH3 over Cu-SAPO-34

\author{
Yu Mao, Ziyun Wang, Hai-Feng Wang, and Peijun Hu
}

ACS Catal., Just Accepted Manuscript • DOI: 10.1021/acscatal.6b01449 • Publication Date (Web): 11 Oct 2016

Downloaded from http://pubs.acs.org on October 14, 2016

\section{Just Accepted}

"Just Accepted" manuscripts have been peer-reviewed and accepted for publication. They are posted online prior to technical editing, formatting for publication and author proofing. The American Chemical Society provides "Just Accepted" as a free service to the research community to expedite the dissemination of scientific material as soon as possible after acceptance. "Just Accepted" manuscripts appear in full in PDF format accompanied by an HTML abstract. "Just Accepted" manuscripts have been fully peer reviewed, but should not be considered the official version of record. They are accessible to all readers and citable by the Digital Object Identifier (DOI®). "Just Accepted" is an optional service offered to authors. Therefore, the "Just Accepted" Web site may not include all articles that will be published in the journal. After a manuscript is technically edited and formatted, it will be removed from the "Just Accepted" Web site and published as an ASAP article. Note that technical editing may introduce minor changes to the manuscript text and/or graphics which could affect content, and all legal disclaimers and ethical guidelines that apply to the journal pertain. ACS cannot be held responsible for errors or consequences arising from the use of information contained in these "Just Accepted" manuscripts. 


\title{
zeolites: A density functional theory study of selective catalytic reduction of $\mathrm{NO}_{x}$ by $\mathrm{NH}_{3}$
}

\section{over Cu-SAPO-34}

\author{
Yu Mao, ${ }^{\dagger, \ddagger}$ Ziyun Wang, ${ }^{\ddagger}$ Hai-Feng Wang, ${ }^{*, \dagger}$ and P. Hu ${ }^{*, \dagger, \ddagger}$ \\ $\dagger$ Key Laboratory for Advanced Materials, Centre for Computational Chemistry and \\ Research Institute of Industrial Catalysis, East China University of Science and \\ Technology, 130 Meilong Road, Shanghai, 200237, China. \\ $\ddagger$ School of Chemistry and Chemical Engineering, The Queen’s University of Belfast, \\ Belfast, BT9 5AG, United Kingdom.
} E-mail: hfwang@ecust.edu.cn; p.hu@qub.ac.uk 


\begin{abstract}
Metal exchanged CHA-type (SAPO-34 and SSZ-13) zeolites are promising catalysts for selective catalytic reduction $(\mathrm{SCR})$ of $\mathrm{NO}_{\mathrm{x}}$ by $\mathrm{NH}_{3}$. However, the understanding of the process at the molecular level is still limited, which hinders the identification of its mechanism and the design of more efficient zeolite catalysts. In this work, modelling the reaction over $\mathrm{Cu}-\mathrm{SAPO}-34$, a periodic density functional theory (DFT) study of $\mathrm{NH}_{3}$-SCR was performed using hybrid functional with the consideration of van der Waals (vdW) interactions. A mechanism with a low $\mathrm{N}-\mathrm{N}$ coupling barrier is proposed to account for the activation of NO. The redox cycle of $\mathrm{Cu}^{2+}$ and $\mathrm{Cu}^{+}$, which is crucial for the SCR process, is identified with detailed analyses. Besides, the decomposition of $\mathrm{NH}_{2} \mathrm{NO}$ is shown to readily occur on the Brønsted acid site by a hydrogen push-pull mechanism, confirming the collective efforts of Brønsted acid and Lewis acid $\left(\mathrm{Cu}^{2+}\right)$ sites. The special electronic and structural properties of Cu-SAPO-34 are demonstrated to play an essential role the reaction, which may have a general implication on the understanding of zeolite catalysis.
\end{abstract}

\title{
Keywords
}

Density functional theory, Selective catalytic reduction, Cu-SAPO-34, Ammonia, Zeolite, Nitric oxide

\section{Introduction}

The reduction of environmentally harmful nitrogen oxides $\left(\mathrm{NO}_{\mathrm{x}}\right)$, especially for these in lean-burn engine exhausts, is currently an important and challenging task for chemical researchers. ${ }^{1-4}$ Among possible solutions, selective catalytic reduction (SCR) of $\mathrm{NO}_{\mathrm{x}}$ by ammonia $\left(\mathrm{NH}_{3}\right.$-SCR) over metal-exchanged CHA-type zeolites has attracted great attention in recent years. As the major N-containing compounds from diesel engines is NO $(>90 \%)$, the 
main reaction of $\mathrm{NH}_{3}$-SCR can be expressed as: ${ }^{5}$

$$
4 \mathrm{NH}_{3}+4 \mathrm{NO}+\mathrm{O}_{2} \longrightarrow 4 \mathrm{~N}_{2}+6 \mathrm{H}_{2} \mathrm{O}
$$

which is usually called the standard SCR. The process with equimolar mixture of NO and $\mathrm{NO}_{2}$, on the other hand, is named the fast SCR that reacts much faster: ${ }^{6}$

$$
2 \mathrm{NH}_{3}+\mathrm{NO}+\mathrm{NO}_{2} \longrightarrow 2 \mathrm{~N}_{2}+2 \mathrm{H}_{2} \mathrm{O}
$$

Prior to zeolites, $\mathrm{NH}_{3}$-SCR techniques have been used with noble metals and metal oxides (e.g., $\mathrm{V}_{2} \mathrm{O}_{5}$-based catalysts) in stationary plants. ${ }^{7-9}$ However, due to the toxicity of $\mathrm{V}_{2} \mathrm{O}_{5}$ species and different catalytic conditions of automobile engines, ${ }^{10}$ zeolites have received great attention as potential $\mathrm{NH}_{3}$-SCR catalysts nowadays. Among all zeolites, a majority of studies in past decade were conducted on copper exchanged small-pore CHA-type zeolites (Cu-SAPO-34 and Cu-SSZ-13) because of their high $\mathrm{NO}_{\mathrm{x}}$ conversion as well as high $\mathrm{N}_{2}$ selectivity, non-toxicity, wider operation temperature ranges, and excellent hydrothermal stability in diesel engines. ${ }^{2-4,10-12} \mathrm{Cu}-\mathrm{SSZ}-13$ is now in commercial use ${ }^{13}$ and received much attention in past several years; SAPO-34 has the same topology with SSZ-13, but with different silica ratio. Kwak et al. ${ }^{14}$ demonstrated that Cu-SSZ-13, compared with Cu-beta and $\mathrm{Cu}-\mathrm{ZSM}-5$, was more active in SCR over the entire temperature range and more selective towards nitrogen formation (less $\mathrm{NO}_{2}$ and $\mathrm{N}_{2} \mathrm{O}$ by-products). Ma et al. ${ }^{15}$ reported that $\mathrm{Cu}-$ SAPO-34 would be more active than Cu-SSZ-13 after hydrothermal treating.

There are two kinds of possible active sites in $\mathrm{Cu}$ exchanged CHA-type zeolites: the Brønsted acid ( $\mathrm{H}$ in the zeolite framework) and Lewis acid (introduced $\mathrm{Cu}$ ion) sites. For the $\mathrm{Cu}$ sites, diffuse reflectance infrared fourier transform (DRIFT) spectroscopy and X-ray absorption spectroscopy (XAFS) showed that they would locate in both six- and eightmembered ring. ${ }^{12,16-18}$ Catalytic experiments of Beale et al. ${ }^{19}$ revealed that the mononuclear $\mathrm{Cu}^{2+}$ in six-membered rings is responsible for $\mathrm{N}_{2}$ production, while the $\mathrm{Cu}$ in eight-membered 
ring $\left(\mathrm{CuAlO}_{2}\right)$ appears to promote the formation of undesired $\mathrm{N}_{2} \mathrm{O}$. They pointed out that the SCR activity is inexorably linked with isolated $\mathrm{Cu}$ on the six-membered ring. DFT calculations also indicated that isolated $\mathrm{Cu}$ ions prefer to lie slightly above the six-membered ring of CHA-type zeolites. ${ }^{20-2825,29-32}$ When $\mathrm{Cu}$ loading is high, $\mathrm{Cu}$ dimers would be formed in the zeolites, ${ }^{33}$ yet they may not be directly related with SCR reactivity. ${ }^{11}$ Xue et al. ${ }^{34}$ reported that the TOF value of SCR would be a function of isolated $\mathrm{Cu}^{2+}$ amount over Cu-SAPO-34. For Brønsted acids, it is currently not well understood what role it is in reaction system. Some studies showed that the Brønsted acid site could catalyse part of the reaction, ${ }^{6,35,36}$ while others argued that its effect is rather limited. ${ }^{11,25,37}$

The nature of $\mathrm{Cu}$ species during the reaction is more complicated. According to the latest research of Schneider et $a{ }^{12}{ }^{12}$ the oxidation state and coordination environment of $\mathrm{Cu}$ would vary as a function of environmental conditions. For example, upon adsorption of $\mathrm{NH}_{3}, \mathrm{NO}$, or $\mathrm{H}_{2} \mathrm{O}$ on the $\mathrm{Cu}$ atoms in six-membered ring, the $\mathrm{Cu}$ atoms may be lift out from their original position into the larger cavities to form $\mathrm{Cu}$ complexes, ${ }^{38-40}$ such as $\mathrm{Cu}\left(\mathrm{H}_{2} \mathrm{O}\right)_{6}$ and $\mathrm{Cu}\left(\mathrm{NH}_{3}\right)_{6} \cdot{ }^{16,25,33,41,42}$ But only $\mathrm{Cu}$ sites near six-membered rings seem to contribute to SCR activity in CHA-type zeolites. ${ }^{19,24,25,43}$ Furthermore, many studies ${ }^{11,23,28,44,45}$ suggested that a mixture of $\mathrm{Cu}(\mathrm{I})-\mathrm{Cu}(\mathrm{II})$ oxidation states co-exist during the standard $\mathrm{SCR}$, and the SCR process will be accompanied by a redox cycle of $\mathrm{Cu}^{+}$and $\mathrm{Cu}^{2+}$. Initially, $\mathrm{Cu}^{2+}$ in the zeolites would be reduced to $\mathrm{Cu}^{+}$by the adsorption of $\mathrm{NO}$ and $\mathrm{NH}_{3}$ to form $\mathrm{N}_{2}$ and $\mathrm{H}_{2} \mathrm{O} \cdot{ }^{28,46,47} \mathrm{NO}$ oxidation then takes place on the $\mathrm{Cu}^{+}$site, regenerating $\mathrm{Cu}^{2+}$ that completes the redox cycle. ${ }^{11,28}$ The presence of $\mathrm{Cu}^{+}$was identified by many experimental investigations, including X-ray photoelectron spectroscopy (XPS) and infrared spectroscopy (IR). ${ }^{23,25,34,44,48}$

Furthermore, the reaction rate of fast SCR (equation 2) is much higher than the standard SCR (equation 1), the intrinsic reason of which is still under debate. Most studies suggested that in the standard SCR process, NO oxidation to $\mathrm{NO}_{2}$ by $\mathrm{O}_{2}$ is the rate-limiting step, ${ }^{11}$ and thus it is much slower than fast SCR which did not require $\mathrm{O}_{2}$ to oxidise NO. For example, Janssens et al. ${ }^{11}$ proposed that $\mathrm{NO}$ and $\mathrm{O}_{2}$ would react on the $\mathrm{Cu}^{+}$site to form 
$\mathrm{NO}_{3}{ }^{-}$, which would further react with $\mathrm{NO}$ to produce $\mathrm{NO}_{2}{ }^{-}$and $\mathrm{NO}_{2}$. In the fast $\mathrm{SCR}, \mathrm{NO}$ and $\mathrm{NO}_{2}$ could also bind in the gas phase to form $\mathrm{N}_{2} \mathrm{O}_{3}$, followed by a hydrolysis to nitrous acid $\left(\mathrm{N}_{2} \mathrm{O}_{3}+\mathrm{H}_{2} \mathrm{O} \longrightarrow 2 \mathrm{HONO}\right) .{ }^{36,49}$ After that, $\mathrm{NH}_{3}$ can easily react with $\mathrm{HONO}$ to form $\mathrm{NH}_{4} \mathrm{NO}_{2}$ that decomposes readily to yield $\mathrm{N}_{2}$ and $\mathrm{H}_{2} \mathrm{O}$ under reaction conditions. ${ }^{2,10,15}$ Tronconi et al., ${ }^{50}$ however, challenged this explanation using the experimental observation that rate of $\mathrm{NO}$ oxidation over zeolites is much slower than the standard SCR.

In addition to above studies, numerous investigations have been carried out on $\mathrm{NH}_{3}-\mathrm{SCR}$ over zeolites; however, several fundamental issues about its mechanism are still not well understood due to the limitations of current experimental techniques on detecting dynamic and instant events at the molecular level. ${ }^{4}$ The large number of possible reactions in SCR system also makes reaction pathways very complicated. Some important questions remain to be answered: (i) how NO is activated and what the role of $\mathrm{O}_{2}$ is; (ii) whether the redox cycle of $\mathrm{Cu}^{2+}$ and $\mathrm{Cu}^{+}$is involved and what the redox mechanism is; (iii) whether both Brønsted acid and Lewis acid collectively catalyse the SCR process. To elucidate these questions, several theoretical attempts have been made by Li et al. ${ }^{6,36}$ and Bruggemann et al. ${ }^{35,51}$ on H-form and Fe exchanged zeolites with cluster models, and some possible reaction pathways were identified. Paolucci et al. ${ }^{28}$ proposed a detailed $\mathrm{NH}_{3}$-SCR mechanism on Cu-SSZ-13 using both operando X-ray absorption experiments and density functional theory (DFT) calculations. $\mathrm{Cu}^{\mathrm{I}} \mathrm{H}_{2} \mathrm{NNO} / \mathrm{H}^{+}$and $\mathrm{Cu}^{\mathrm{II}} \mathrm{NO}_{2} / \mathrm{NH}_{4}{ }^{+}$complexes, according to their study, were involved in the reducing and oxidising parts of the whole reaction, respectively. Very recently, Janssens et al. ${ }^{11}$ proposed a consistent scheme of $\mathrm{NH}_{3}$-SCR over Cu-SSZ-13. They described a complete catalytic cycle with correct stoichiometry while allowing adsorption and desorption of stable molecules only. Despite aforementioned studies, a comprehensive first principles investigation of $\mathrm{NH}_{3}$-SCR over $\mathrm{Cu}-\mathrm{SAPO}-34$, to the best of our knowledge, has not been performed yet. In this contribution, we explore the reaction by DFT calculations with hybrid (HSE06) functional to answer above three questions. Van der Waals (vdW) interactions were also included to accurately describe the system. A detailed step-by-step $\mathrm{NH}_{3}$-SCR 
mechanism over $\mathrm{Cu}-\mathrm{SAPO}-34$ were obtained with moderate energy barriers and reasonable intermediate structures. Our results show that the high activity of zeolites on catalysing $\mathrm{NH}_{3}$-SCR are closely related to their structural and electronic properties, including special six-membered ring structure, influence of the framework $\mathrm{H}$ on the valence of loaded metal ion, and collective efforts by Brønsted acid and Lewis acid sites. Our study extends beyond what have been published on SSZ-13, providing both insight into SCR catalysts and zeolite chemistry.

\section{Computational methods}

All calculations in the paper were carried out with the Heyd-Scuseria-Ernzerhof (HSE06) functional ${ }^{52-54}$ using the Vienna ab initio simulation package (VASP). ${ }^{55,56}$ The D3 correction method ${ }^{57}$ was employed in order to include van der Waals (vdW) interactions, which may not be ignorable in zeolites due to their porous structure. The project-augmented wave (PAW) method was used to represent the core-valence interaction. ${ }^{58,59}$ For the calculations of total energy, a cut-off energy of $400 \mathrm{eV}$ was set for plane wave basis sets to expand the valence electronic states and spin-polarization was included. Transition states (TS) were determined by a constrained optimization scheme, ${ }^{60,61}$ in which TSs are verified until (i) all forces on atoms vanish and (ii) the total energy reaches maximum along the reaction coordination but minimum with respect to the rest of the degrees of freedom. For computational efficiency, the geometrical optimization was firstly calculated by Perdew-Burke-Ernzerhof (PBE) functional; ${ }^{62}$ all atoms were fully relaxed until the forces were lower than $0.05 \mathrm{eV} / \AA$. Then HSE06 functional was employed to obtain the accurate total energy. To obtain the free energy of species, some standard formulas of statistical mechanics were used to calculate the thermodynamic correction including zero-point-energy (ZPE), thermal energy and entropy derived from partition functions. ${ }^{63,64}$ (see SI-1 for details).

As we mentioned in the introduction, SAPO-34 is a specific type of silicoaluminophos- 
phate zeolite with chabazite (CHA) structure; ${ }^{65}$ the composition of unit cell is $\mathrm{H}_{\mathrm{x}} \mathrm{Si}_{\mathrm{x}} \mathrm{Al}_{6} \mathrm{P}_{6-\mathrm{x}} \mathrm{O}_{24}$. Experimentally, the of $\mathrm{Si}$ in SAPO-34 $(\mathrm{Si} /(\mathrm{Si}+\mathrm{Al}+\mathrm{P}))$ is usually larger than $0.1,{ }^{66,67}$ and the value of $x$ can be up to 1.32 as a result of magic-angle spinning NMR analysis. ${ }^{68,69}$ In this work, we built a Cu-SAPO-34 $(1 \times 1 \times 2)$ supercell with a $x$ value of 1.5 to represent the zeolite. Two H atoms were removed from the supercell to compensate the positive charge of the introduced $\mathrm{Cu}^{2+}$ ion, and the final chemical formula of the supercell is $\mathrm{CuHSi}{ }_{3} \mathrm{Al}_{12} \mathrm{P}_{9} \mathrm{O}_{48}$. Similar models have been employed by Termath et $a l .{ }^{70}$ and Uzunova et al. ${ }^{68,71,72}$ This model is reasonable for investigating the $\mathrm{NH}_{3}$-SCR process since both Brønsted acid (H) and Lewis acid $(\mathrm{Cu})$ are included in the supercell. During the calculations, the Brillouin zone was sampled at the gamma point, which is appropriate for this insulator. ${ }^{12}$ The adsorption energy $\left(\Delta G_{a d}\right)$ was defined as:

$$
\Delta G_{a d}=G_{a d s o r b a t e+z e o l i t e}-G_{\text {adsorbate }}-G_{\text {zeolite }}
$$

where $G_{z e o l i t e}, G_{\text {adsorbate, }}$, and $G_{\text {adsorbate+zeolite }}$ are the free energies of the zeolite, adsorbate in the gas phase, and adsorbate adsorbed on the zeolite, respectively.

\section{Results and discussion}

\section{Structure of the Cu-SAPO-34 and the adsorption of gas phase molecules}

The optimized Cu-SAPO-34 supercell is displayed in Fig. 1. Under low $\mathrm{Cu}$ loading content, as mentioned in the introduction, $\mathrm{Cu}$ was suggested to locate slightly above the six-membered ring near two Si atoms (position 1 in Fig. $1 b)^{2,14}$ as a divalent ion $\left(\mathrm{Cu}^{2+}\right)$. To validate this view, we examined the energies of $\mathrm{Cu}-\mathrm{SAPO}-34$ with $\mathrm{Cu}^{2+}$ in different positions (1-5 in Fig. 1b) and ensured that position 1 is the most stable one (Tab. S1 in SI). We can see from the figure that $\mathrm{Cu}$ is coordinated with four $\mathrm{O}$ atoms in the six-membered ring with distances of $2.08,1.95,1.91$, and $2.36 \AA$, which are quite similar to the results of Uzunova et al. ${ }^{68,71,72}$ 
There are two Si atoms in the ring, while the remaining $\mathrm{Si}$ is accompanied by a $\mathrm{H}$ atom to form a Brønsted acid site. The stabilities of different $\mathrm{H}$ positions (1-4 in Fig. 1a) were also tested. Positions 1-4 show very close stabilities, among which position 1 is slightly preferable (Tab. S2 in SI). The volume of the relaxed supercell was calculated to be $1662.5 \AA^{3}$, very close to the experimental value $\left(1644.8 \AA^{3}\right) .{ }^{69,73}$
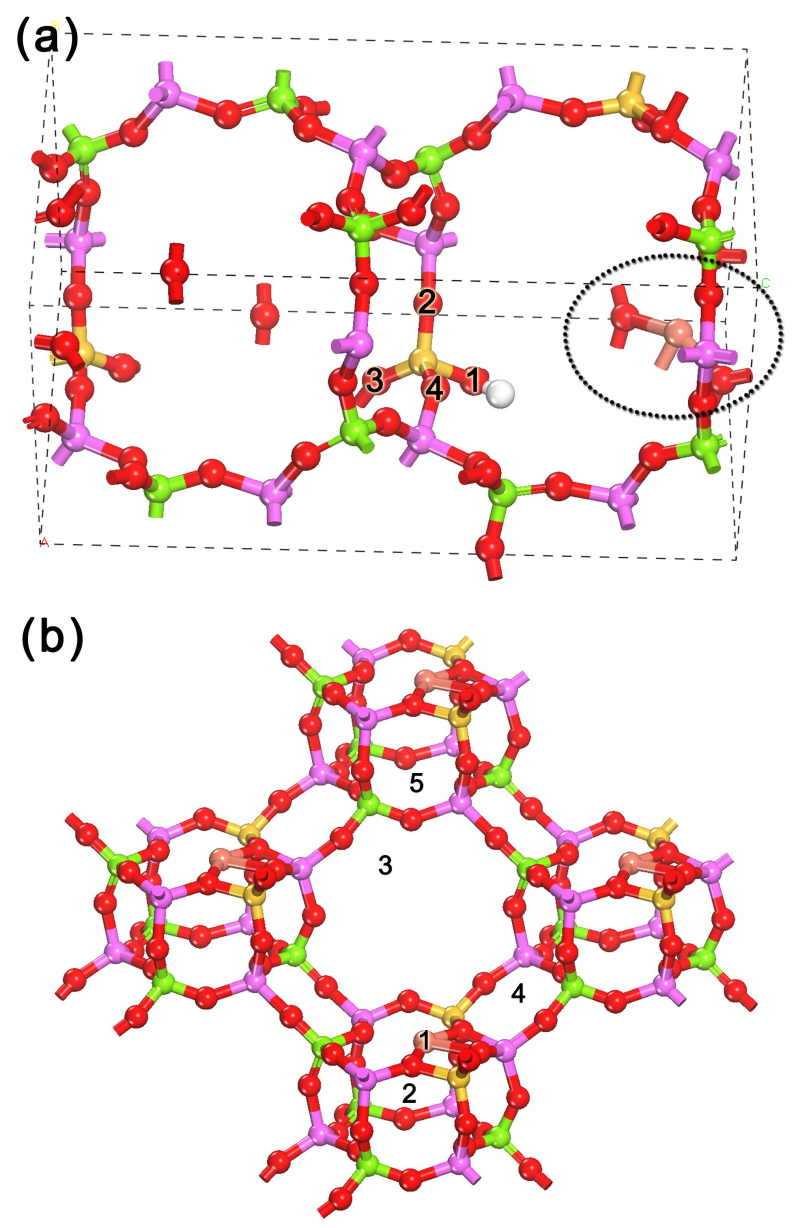

Figure 1: Structural illustrations of the (a) Cu-SAPO-34 supercell; (b) periodic view of the elliptical circle in (a). Green, red, purple, yellow, brown, and white balls represent P, O, Al, $\mathrm{Si}, \mathrm{Cu}$, and $\mathrm{H}$ atoms, respectively. This notation will be used throughout the paper.

In reaction equations (1) and (2), the reactants of $\mathrm{SCR}$ are $\mathrm{NH}_{3}, \mathrm{NO}, \mathrm{O}_{2}$, and $\mathrm{NO}_{2}$. We subsequently investigated the adsorption of these species and water on both Brønsted acid (B-site) and Lewis acid (L-site) sites, the best adsorption structures of which are illustrated in Fig. 2. In the figure, $\mathrm{H}_{2} \mathrm{O}$ exhibit moderate adsorption on B- and L-sites, while both $\mathrm{NO}_{2}$ 

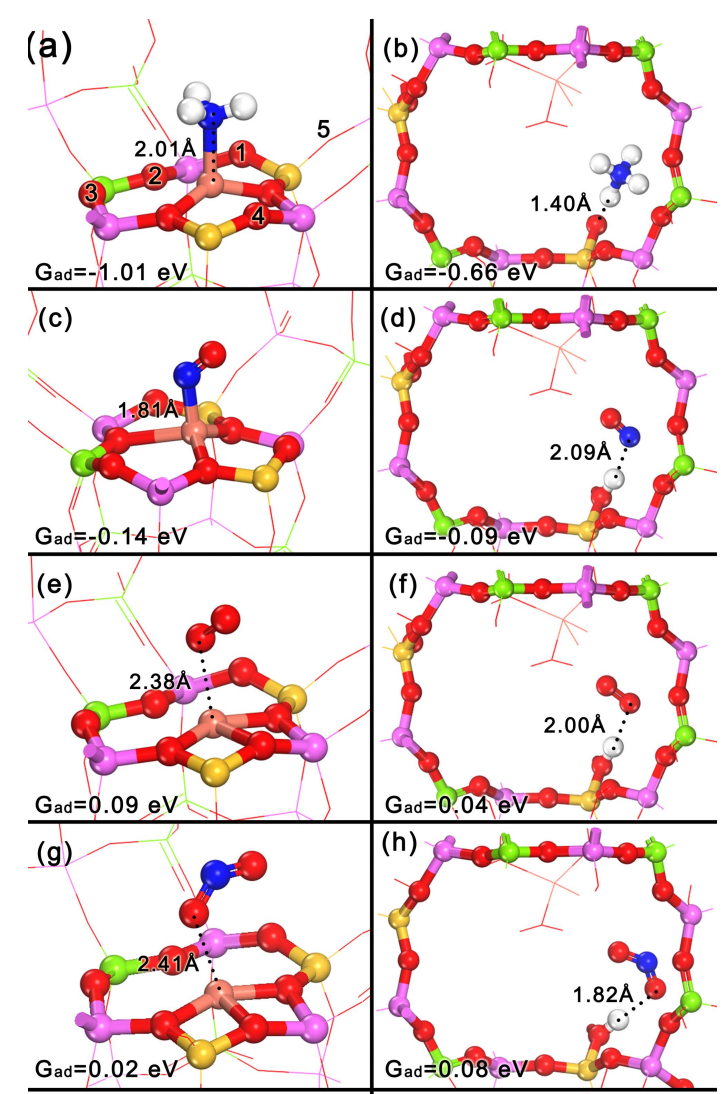

(i)

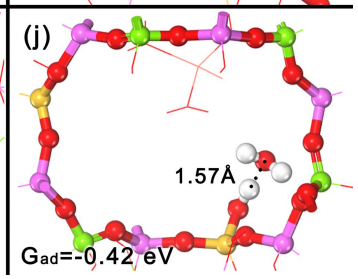

Figure 2: Structural illustration of the adsorption of $\mathrm{NH}_{3}(\mathrm{ab}), \mathrm{NO}(\mathrm{cd}), \mathrm{O}_{2}$ (ef), $\mathrm{NO}_{2}$ (gh), and $\mathrm{H}_{2} \mathrm{O}(\mathrm{ij})$. The left and right columns refer to the Lewis acid $\left(\mathrm{Cu}^{2+}\right)$ and Brønsted acid (H) site, respectively.

and $\mathrm{O}_{2}$ hardly adsorb on the zeolite. NO prefers to slightly bond with the $\mathrm{Cu}^{2+}$ ion by its $\mathrm{N}$ end. $\mathrm{NH}_{3}$ binds strongly on both sites, and it will exist as $\mathrm{NH}_{4}^{+}$on B-sites. The results indicate that L-sites will be dominantly covered by $\mathrm{NH}_{3}$ and a small amount of $\mathrm{NO}$ at the start of SCR process, and the B-site by $\mathrm{NH}_{3}$. It is in accordance with the generally accepted opinion that $\mathrm{NH}_{3}$ and $\mathrm{NO}$ shall react on L-sites whereas B-sites sever as a $\mathrm{NH}_{3}$ reservoir in the beginning of the reaction. ${ }^{4,74}$ The $\mathrm{NH}_{3}$ on B-sites could migrate to L-sites as the reaction proceeds. 


\section{Formation of the $\mathrm{N}-\mathrm{N}$ bond}

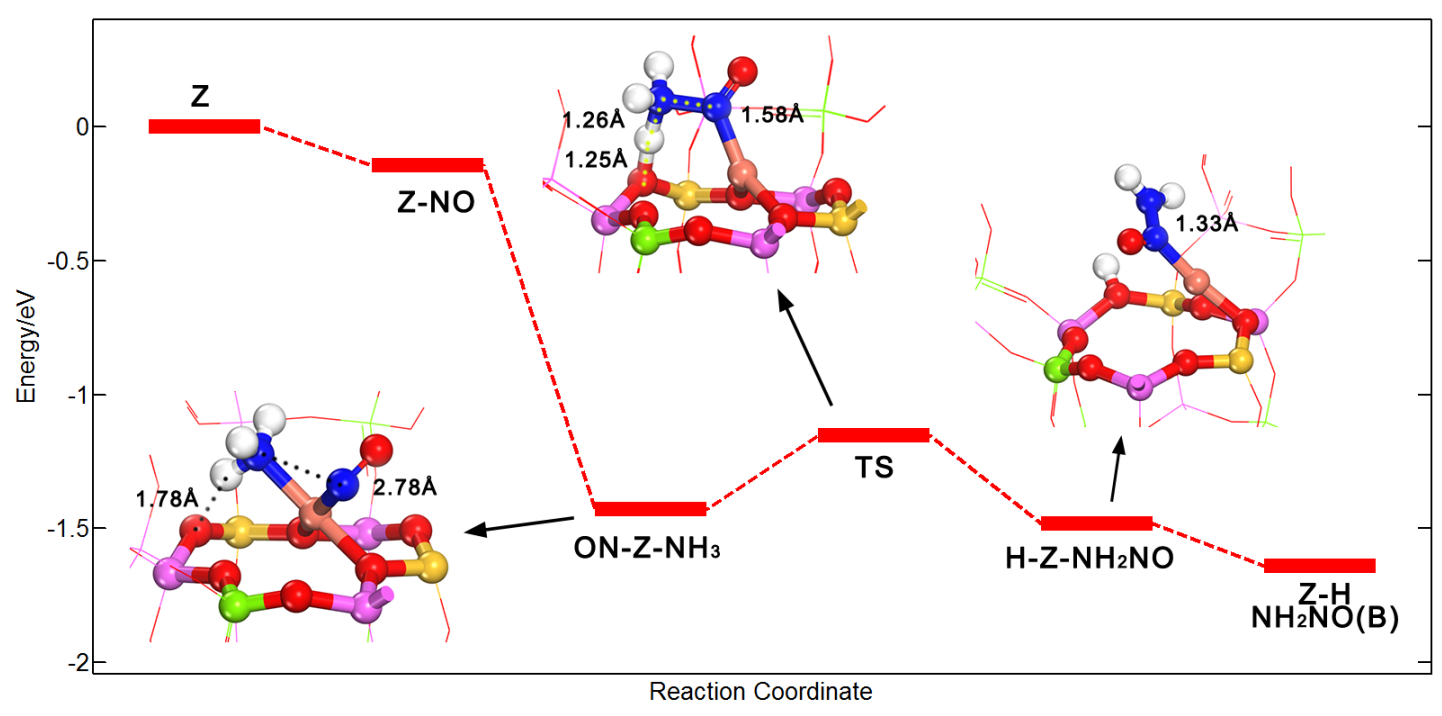

Figure 3: Free energy profile of the N-N coupling process. Some key structures are illustrated as inserts. (B) in the $\mathrm{NH}_{2} \mathrm{NO}$ (B) indicates that it has been transferred to a Brønsted acid site.

The full mechanism of $\mathrm{NH}_{3}$-SCR is considerably complicated. ${ }^{3,10}$ Among that, $\mathrm{N}-\mathrm{N}$ coupling is a crucial step towards the formation of nitrogen; therefore, it will be investigated first in this paper. Considering the valence of $\mathrm{N}$ in $\mathrm{N}_{2}(0)$, the coupling of two $\mathrm{N}$ atoms shall come from $\mathrm{NH}_{3}(-3)$ and $\mathrm{NO}(+2)$, respectively. According to this principle, we tried numerous possible reaction schemes of $\mathrm{NO}$ with $\mathrm{NH}_{3}$ in order to form $\mathrm{N}-\mathrm{N}$ bond, but all of them failed: a huge repulsion would occur when $\mathrm{N}$ in $\mathrm{NO}$ approaches $\mathrm{NH}_{3}$; the $\mathrm{NO}$ would be pushed away if they are forced to be close. This is reasonable since $\mathrm{N}$ in $\mathrm{NH}_{3}$ is saturated (Fig. 2a); therefore, the possibility of direct attacking of $\mathrm{NO}$ to $\mathrm{NH}_{3}$ is ruled out. Then, in order to circumvent the problem of saturated $\mathrm{NH}_{3}$, we tried to remove one $\mathrm{H}$ from the $\mathrm{NH}_{3}$ to form $\mathrm{NH}_{2}$ because $\mathrm{NH}_{2}$ is unsaturated, which would be easier for NO to react. Five positions indicated in Fig. 2a were considered to locate $\mathrm{H}$ after $\mathrm{NH}_{3}$ decomposition. However, from the results in Fig. S1, we found that all these pathways are extremely unfavourable thermodynamically; their free energies are $0.94 \sim 1.98 \mathrm{eV}$ higher than that in Fig. 2a, let alone kinetic barriers. So, it would be very difficult to directly remove one $\mathrm{H}$ from $\mathrm{NH}_{3}$. 
Since both of above reaction schemes are very difficult to occur over zeolites, we considered if other species in SCR reaction could facilitate the process. After numerous attempts and calculations, we found that with the assistance of $\mathrm{NO}$, the $\mathrm{N}-\mathrm{H}$ bond breaking would be much easier:

$$
\mathrm{NH}_{3}+\mathrm{NO}+\mathrm{Z} \longrightarrow \mathrm{NH}_{2} \mathrm{NO}+\mathrm{Z}-\mathrm{H}
$$

where Z indicates the zeolite. We subsequently investigated relevant intermediates and transition states of the reaction, whose structures and energies are displayed in Fig. 3. It proves that with NO, the reaction barrier would be much lower compared with dehydrogenation of $\mathrm{NH}_{3}$ alone. In Fig. 3, $\mathrm{NO}$ and $\mathrm{NH}_{3}$ would adsorb on the $\mathrm{Cu}^{2+}$ with considerable free energy declines $(1.43 \mathrm{eV})$. It is worth noting that in the insert $\left(\mathrm{ON}-\mathrm{Z}-\mathrm{NH}_{3}\right)$ of Fig. 3, one $\mathrm{H}$ in the $\mathrm{NH}_{3}$ is quite close to a framework $\mathrm{O}(1.78 \AA)$, indicating a hydrogen bond interaction between them. Then, in the transition state, $\mathrm{NH}_{3}$ would approach the framework $\mathrm{O}$, intending to bond it with the $\mathrm{H}$. The distance between two $\mathrm{N}$ atoms, at the same time, is shortened $(1.58 \AA)$. Finally, since the bonding of two N would release a large amount of energy compensating the energy needed to break the $\mathrm{N}-\mathrm{H}$ bond in $\mathrm{NH}_{3}$, two $\mathrm{N}$ atoms couple to form $\mathrm{NH}_{2} \mathrm{NO}$ while the $\mathrm{H}$ remains on the framework $\mathrm{O}$ (insert $\mathrm{H}-\mathrm{Z}-\mathrm{NH}_{2} \mathrm{NO}$ in Fig. 3). The energy barrier for this process was calculated to be $0.28 \mathrm{eV}$, an exceptionally small value, indicating that reaction 4 is a very effective way to activate the $\mathrm{NO}$ in $\mathrm{NH}_{3}$-SCR. We further made a frequency analysis to ensure its accuracy. The results showed that the transition state here exhibited one and only one imaginary frequency, which corresponds to $\mathrm{N}-\mathrm{N}$ coupling and $\mathrm{N}-\mathrm{H}$ breaking with a value of $450.5 i \mathrm{~cm}^{-1}$. The $\mathrm{NH}_{2} \mathrm{NO}$ would transfer to B-sites for further decomposition, which will be demonstrated in the last subsection. In addition, we made a Bader analysis on $\mathrm{Cu}$ ion before $(\mathrm{Z})$ and after $(\mathrm{Z}-\mathrm{H}) \mathrm{N}-\mathrm{N}$ coupling reaction, finding that the valence of $\mathrm{Cu}$ ion changes from 1.12 to 0.69 which means that $\mathrm{Cu}^{2+}$ is partly reduced to $\mathrm{Cu}^{+}$. The result is quite reasonable, since we can see from the left column of Fig. 2 and schemes in Fig. 3 that before $\mathrm{N}-\mathrm{N}$ coupling, $\mathrm{Cu}^{2+}$ ion tend to coordinate with four atoms, while the coordination number of $\mathrm{Cu}^{+}$, after the reaction, becomes two (scheme $\mathrm{H}-\mathrm{Z}-\mathrm{NH}_{2} \mathrm{NO}$ in Fig. 
3). The results agree well with the general principle in coordination chemistry. Deep insight into the valence change of $\mathrm{Cu}$ ion and the intrinsic reason why the reaction can happen over zeolites by such an low-energy-barrier mechanism will be presented in the discussion section.

\section{$\mathrm{NO}$ and $\mathrm{Cu}^{+}$oxidation by $\mathrm{O}_{2}$}

Although the whole reaction is the reduction of $\mathrm{NO}_{\mathrm{x}}, \mathrm{O}_{2}$ plays a crucial role in the SCR process. ${ }^{4,10}$ Some researchers argued that in standard $\mathrm{SCR} \mathrm{O}_{2}$ will oxidise NO into $\mathrm{NO}_{2}$, resulting a fast SCR; however, other studies argued that standard and fast SCR may exhibit distinct mechanisms. ${ }^{50,75}$ Currently, a clear mechanism for $\mathrm{NO}$ oxidation to $\mathrm{NO}_{2}$ on the $\mathrm{Cu}$ ion is under debate and have not been achieved yet. Some previous studies stated that NO was oxidised by $\mathrm{O}_{2}$ in the gas phase or in pores of zeolites $\left(\mathrm{O}_{2}+2 \mathrm{NO} \longrightarrow 2 \mathrm{NO}_{2}\right),{ }^{36}$ but it is a three-molecule reaction thus its contribution to the overall NO oxidation is limited. We suggest that the elementary reaction is

$$
\mathrm{O}_{2}+\mathrm{NO}+\mathrm{Z}-\mathrm{H}\left(\mathrm{Z}-\mathrm{NH}_{4}\right) \longrightarrow \mathrm{NO}_{2}+\mathrm{O} *-\mathrm{Z}-\mathrm{H}\left(\mathrm{O} *-\mathrm{Z}-\mathrm{NH}_{4}\right)
$$

where the metal ion sites play the main role. $\mathrm{Z}-\mathrm{H}$ in equation 5 means that a $\mathrm{H}$ resides on the framework $\mathrm{O}$ of the six-membered ring (Fig. S2a), and $\mathrm{O}^{*}$ indicates an adsorbed $\mathrm{O}$ atom over the $\mathrm{Cu}$ ion. It should be noted that $\mathrm{NH}_{3}$ can readily adsorb on this $\mathrm{H}$ site $\left(G_{a d}=-1.19\right.$ $\mathrm{eV}$ ), forming $\mathrm{NH}_{4}{ }^{+}$on the ring $\left(\mathrm{Z}-\mathrm{NH}_{4}\right.$, Fig. S2b). Then, we investigated the adsorption of $\mathrm{O}_{2}$ on $\mathrm{Cu}$ ion site as well as the energy barriers and free energy change of above reaction, the energy diagrams of which are shown in Fig. 4.

From the results, we can notice that the adsorption energy of $\mathrm{O}_{2}$ increases significantly after $\mathrm{Cu}^{2+}$ being reduced to $\mathrm{Cu}^{+}$with a $\mathrm{H}$ on the six-membered ring $\left(G_{a d}\right.$ from $0.52 \mathrm{eV}$ to $\sim 0 \mathrm{eV})$. Then, effective energy barriers on $\mathrm{Cu}^{+}$site $\left(\mathrm{Z}-\mathrm{H} 1.06 \mathrm{eV}\right.$ and $\left.\mathrm{Z}-\mathrm{NH}_{4} 0.86 \mathrm{eV}\right)$ is found to be much lower than that on $\mathrm{Cu}^{2+}(3.65 \mathrm{eV})$. This agree well with the previous work that $\mathrm{Cu}^{2+}$ ions are incapable of activating $\mathrm{O}_{2},{ }^{76}$ and $\mathrm{Cu}^{+}$plays role of catalysing $\mathrm{NO}$ 


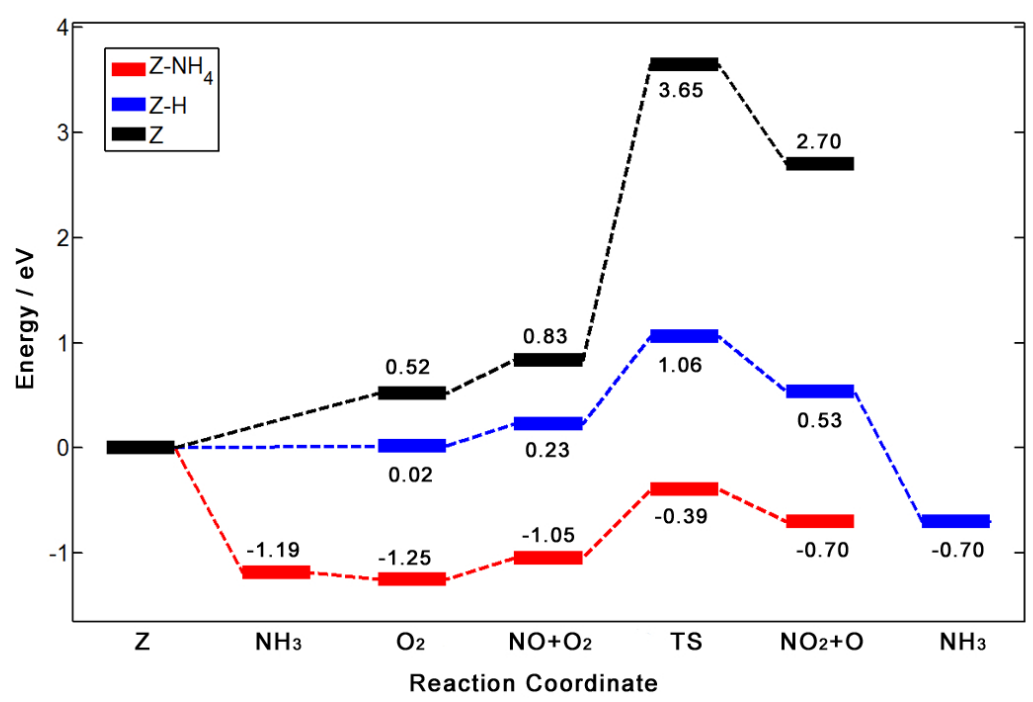

Figure 4: Free energy diagrams of $\mathrm{O}_{2}$ oxidation on zeolite (Z, black), Z-H (blue), and Z- $\mathrm{NH}_{4}$ (red). For $\mathrm{Z}$ and $\mathrm{Z}-\mathrm{H}$ pathway, $\mathrm{O}_{2}$ and $\mathrm{NO}$ will adsorb on $\mathrm{Cu}$ site and react to yield $\mathrm{NO}_{2}$ and $\mathrm{O}$ through the transition state, $\mathrm{NH}_{3}$ will adsorb on $\mathrm{Z}-\mathrm{H}$ after that (corresponding to structures in Fig. S2(a, c) and Fig $5(\mathrm{~b}, \mathrm{~d}, \mathrm{f})$; for $\mathrm{Z}-\mathrm{NH}_{4}$ pathway, one $\mathrm{NH}_{3}$ would adsorb first, then followed by $\mathrm{O}_{2}$, $\mathrm{NO}$ adsorption and the transition state (corresponding to structures in Fig. S2(b, d) and Fig. S3(b, d, f))

oxidation. ${ }^{11}$ We also considered the attacking of $\mathrm{NO}$ to $\mathrm{O}_{2}$ from gas phase (Fig. S3(a, c, e) and Fig. 5(a, c, e)), the energy barriers of which are over $1 \mathrm{eV}$, unfavourable compared with $\mathrm{NO}$ and $\mathrm{O}_{2}$ co-adsorbing on $\mathrm{Cu}$ site. After that, the produced $\mathrm{NO}_{2}$ can react with its neighbouring $\mathrm{NH}_{4}{ }^{+}$(Fig. S3f or Fig. 5f with $\mathrm{NH}_{3}$ adsorption) to form $\mathrm{NH}_{4} \mathrm{NO}_{2}$, leaving an $\mathrm{O}$ atom over the zeolite. The left $\mathrm{O}$ atom is very active and can readily react with NO to form $\mathrm{NO}_{2}$ with a considerable energy decline of $2.67 \mathrm{eV}$. Therefore, the $\mathrm{NO}$ oxidation reaction over $\mathrm{Cu}-\mathrm{SAPO}-34$ zeolites can be expressed as follows:

$$
\mathrm{O}_{2}+2 \mathrm{NO}+\mathrm{NH}_{3}+\mathrm{Z}-\mathrm{H} \longrightarrow \mathrm{NH}_{4} \mathrm{NO}_{2}+\mathrm{NO}_{2}+\mathrm{Z}
$$

It is well recognized that $\mathrm{NH}_{4} \mathrm{NO}_{2}$ is easy to stoichiometrically decompose into $\mathrm{N}_{2}$ and $\mathrm{H}_{2} \mathrm{O}$ under SCR operation condition: $2,4,10,15$

$$
\mathrm{NH}_{4} \mathrm{NO}_{2} \longrightarrow \mathrm{N}_{2}+2 \mathrm{H}_{2} \mathrm{O}
$$




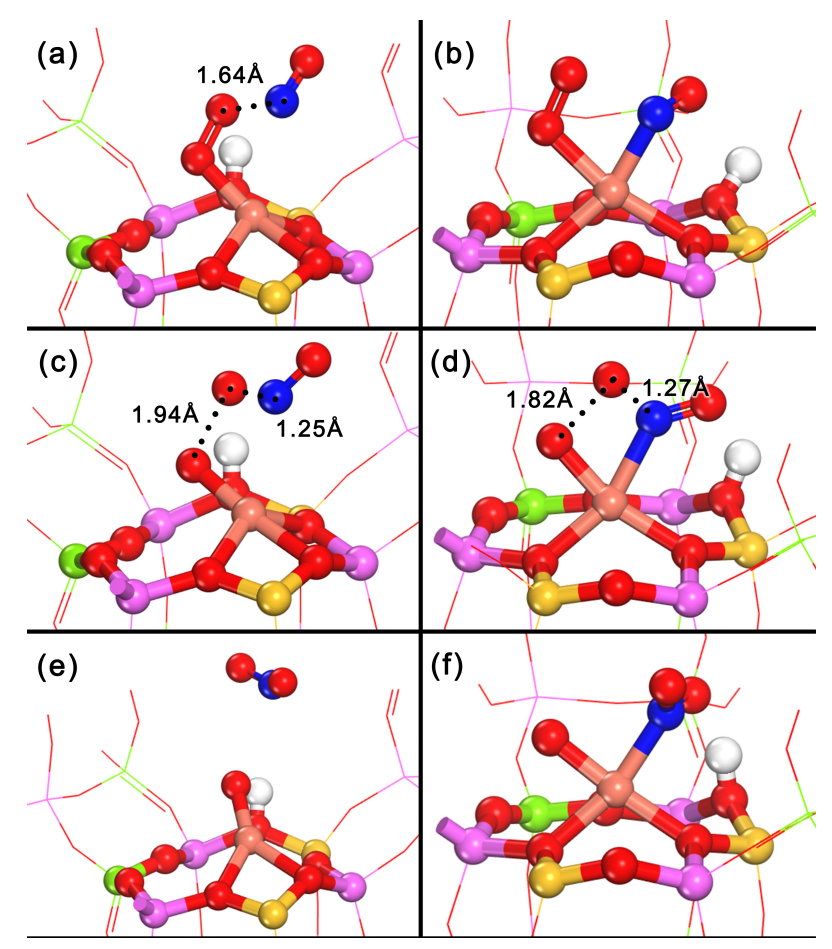

Figure 5: Structural illustration of $\mathrm{NO}$ oxidation on the reduced $\mathrm{Cu}$ ion site (Z-H). (a, b), $(\mathrm{c}, \mathrm{d})$, and $(\mathrm{e}, \mathrm{f})$ correspond to the initial, transition, and final states, respectively. In the left column, $\mathrm{NO}$ attacks from the gas phase while $\mathrm{NO}$ and $\mathrm{O}_{2}$ co-adsorbed in the right.

To sum up, reaction 4 and 5 not only couple the $\mathrm{N}-\mathrm{N}$ bond and form $\mathrm{NH}_{2} \mathrm{NO}$ and $\mathrm{NH}_{4} \mathrm{NO}_{2}$, but also consist a redox cycle. Intuitively, the involvement of a redox cycle is quite reasonable because from equation 4 and 6 , we can see that the reaction ratio of $\mathrm{NH}_{3}$ and $\mathrm{NO}$ is $1: 1$, while the oxidation states of $\mathrm{N}$ in them is a mismatch $\left(-3\right.$ in $\mathrm{NH}_{3}$ and +2 in NO). Therefore, the coupling of $\mathrm{N}-\mathrm{N}$ bond in $\mathrm{NH}_{3}$ and $\mathrm{NO}$ must be accompanied by the reduction of L-site $\left(\mathrm{Cu}^{2+} \longrightarrow \mathrm{Cu}^{+}\right)$which will be regenerated by the oxidation of $\mathrm{O}_{2}$. The redox cycle explains well the experimental observation that steady state NO conversion would decrease to zero after $\mathrm{O}_{2}$ cut-off under standard SCR conditions. ${ }^{28}$ According to their study, the content of $\mathrm{Cu}^{+}$increases to $75-95 \%$ of the whole $\mathrm{Cu}$ species, and $\mathrm{SCR}$ reactions would be soon stopped since $\mathrm{N}-\mathrm{N}$ coupling cannot happen on $\mathrm{Cu}^{+}$site.

If we consider fast $\mathrm{SCR}$ (reaction 2) with $\mathrm{NO}_{2}$ involved, $\mathrm{NO}$ oxidation is not necessary 
after $\mathrm{N}-\mathrm{N}$ coupling and the reaction goes as follows:

$$
\mathrm{NO}_{2}+\mathrm{NH}_{3}+\mathrm{Z}-\mathrm{H} \longrightarrow \mathrm{NH}_{4} \mathrm{NO}_{2}+\mathrm{Z}
$$

$\mathrm{NO}_{2}$ and $\mathrm{NH}_{3}$ can strongly adsorb on $\mathrm{Cu}^{+}$and framework $\mathrm{H}\left(G_{a d}=-0.86\right.$ and $-1.19 \mathrm{eV}$ in Fig. S2e and $\mathrm{S} 2 \mathrm{~b}$, respectively), and $\mathrm{NO}_{2}$ can naturally attack its neighbouring $\mathrm{NH}_{4}^{+}$to form $\mathrm{NH}_{4} \mathrm{NO}_{2}$ (Fig. S2f). ${ }^{28}$

After $\mathrm{N}-\mathrm{N}$ coupling (equation 4) and NO oxidation (equation 6), the copper restores to $\mathrm{Cu}^{2+}$ and the remaining reactants for standard $\mathrm{SCR}$ are one $\mathrm{NO}, \mathrm{NO}_{2}$ and two $\mathrm{NH}_{3}$. Interestingly, these are exactly the reactants of fast SCR (reaction 2), which would be complete through reaction 4,8 , and 7 . It should be noted that we also tried another mechanism after NO oxidation, which is shown is supporting information 5 .

\section{$\mathrm{NH}_{2} \mathrm{NO}$ decomposition into $\mathrm{H}_{2} \mathrm{O}$ and $\mathrm{N}_{2}$}

The $\mathrm{NH}_{2} \mathrm{NO}$ formed in above stages will decompose into $\mathrm{H}_{2} \mathrm{O}$ and $\mathrm{N}_{2}$ to complete the whole SCR process. Previous studies showed that it is a relatively easy process on the B-site of zeolites by a hydrogen push-pull mechanism. ${ }^{35,36}$ We investigated its decomposition on both Brønsted acid and Lewis acid sites, and all intermediates and transition states were identified (Fig. S5). It can be seen from the scheme in Fig. 6 that the configuration of $\mathrm{NH}_{2} \mathrm{NO}$ will change several times by the transferring of $\mathrm{H}$ atom, which was well recognised by previous studies. ${ }^{36,77}$ We firstly tried this process on the L-site (Fig. S5), but the energy barrier of the first step of $\mathrm{NH}_{2} \mathrm{NO}$ decomposition in L-acid, the proton transferring from $\mathrm{N}$ to $\mathrm{O}$, was very high $(2.03 \mathrm{eV})$. From Fig. S5b, we can see that during the intra-molecular proton transfer, an unstable four-membered ring is formed, exerting a strong steric hindrance and making L-side unfavourable for catalysing this reaction. On the other hand, energy barriers of the reactions on the B-site are moderate, making it easy to occur (the energy profile in Fig. 6, and corresponding structures in Fig. S6). 


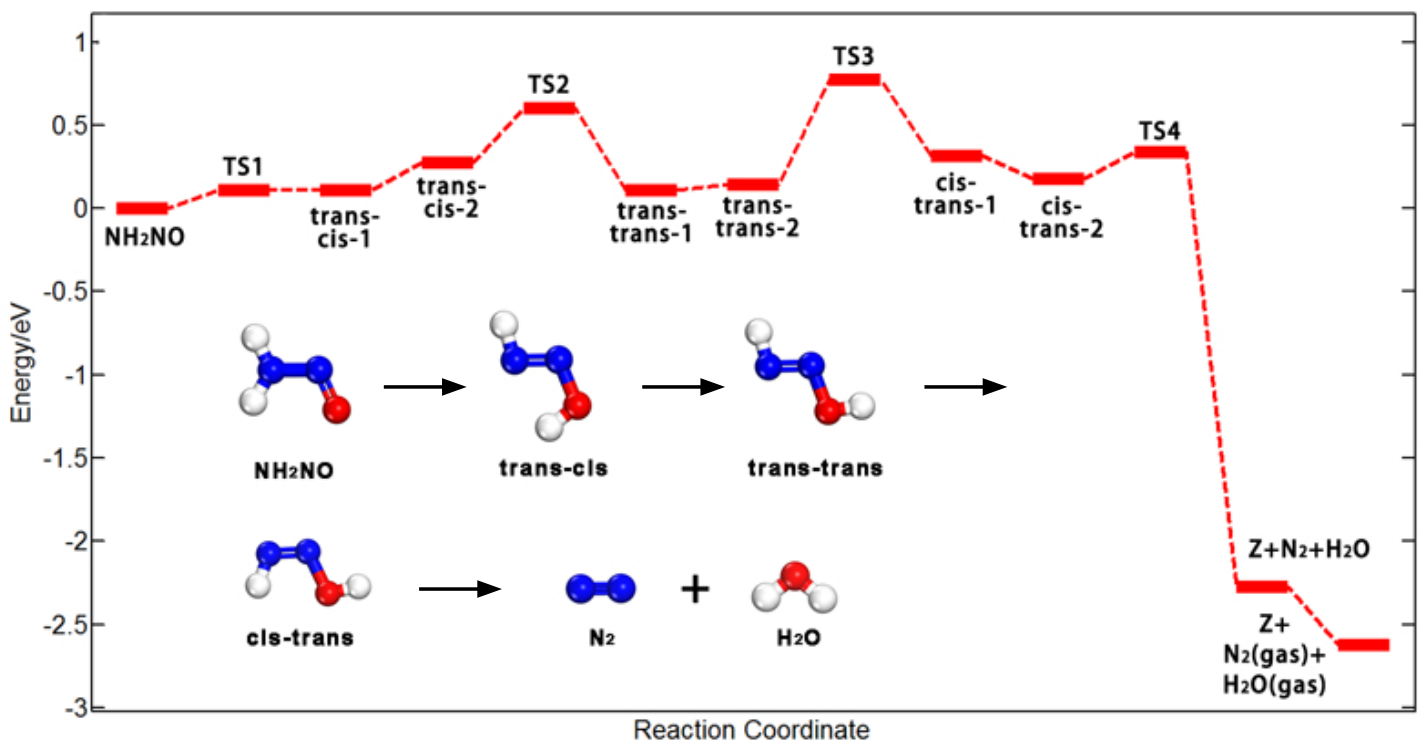

Figure 6: Total energy profile of $\mathrm{NH}_{2} \mathrm{NO}$ decomposition on the B-site and a scheme of transformation of $\mathrm{NH}_{2} \mathrm{NO}$. Structures of intermediates and transition are displayed in Fig. S6.

As shown in Fig. $\mathrm{S} 6 \mathrm{a}, \mathrm{NH}_{2} \mathrm{NO}$ adsorbs on the B-site by the interaction between $\mathrm{O}$ and $\mathrm{H}$ atoms, in which the B-site severs as a $\mathrm{H}$ reservoir, helping $\mathrm{NH}_{2} \mathrm{NO}$ to transfer $\mathrm{H}$ by the so-called hydrogen push-pull mechanism. In the subsequent steps, $\mathrm{NH}_{2} \mathrm{NO}$ transforms its configuration several times by donating and receiving $\mathrm{H}$ with the help of the framework and finally decomposes to $\mathrm{N}_{2}$ and $\mathrm{H}_{2} \mathrm{O}$ with considerable energy release. The highest effective barrier ${ }^{63,78}$ for the $\mathrm{NH}_{2} \mathrm{NO}$ decomposition is $0.77 \mathrm{eV}$ (from $\mathrm{NH}_{2} \mathrm{NO}$ to TS3), which is much lower than that on the L-site. The results show that Brønsted acid and Lewis acid $\left(\mathrm{Cu}^{2+}\right)$ sites would collectively catalyse $\mathrm{NH}_{3}$-SCR over $\mathrm{Cu}-\mathrm{SAPO}-34$ zeolites.

\section{Overall mechanism}

An overall picture of $\mathrm{NH}_{3}$-SCR over $\mathrm{Cu}-\mathrm{SAPO}-34$ is schematically illustrated in Fig. 7. To the best of our knowledge, it is the first time that such a step-by-step reaction pathways of $\mathrm{NH}_{3}$-SCR over Cu-SAPO-34 is presented from periodic DFT calculations. For the standard $\mathrm{SCR}$, the reaction is initialized by $\mathrm{N}-\mathrm{N}$ coupling between $\mathrm{NO}$ and $\mathrm{NH}_{3}$ that co-adsorbed on the $\mathrm{Cu}^{2+}$ site to form $\mathrm{NH}_{2} \mathrm{NO}$; then, $\mathrm{NO}$ is oxidised by $\mathrm{O}_{2}$, which further react with 


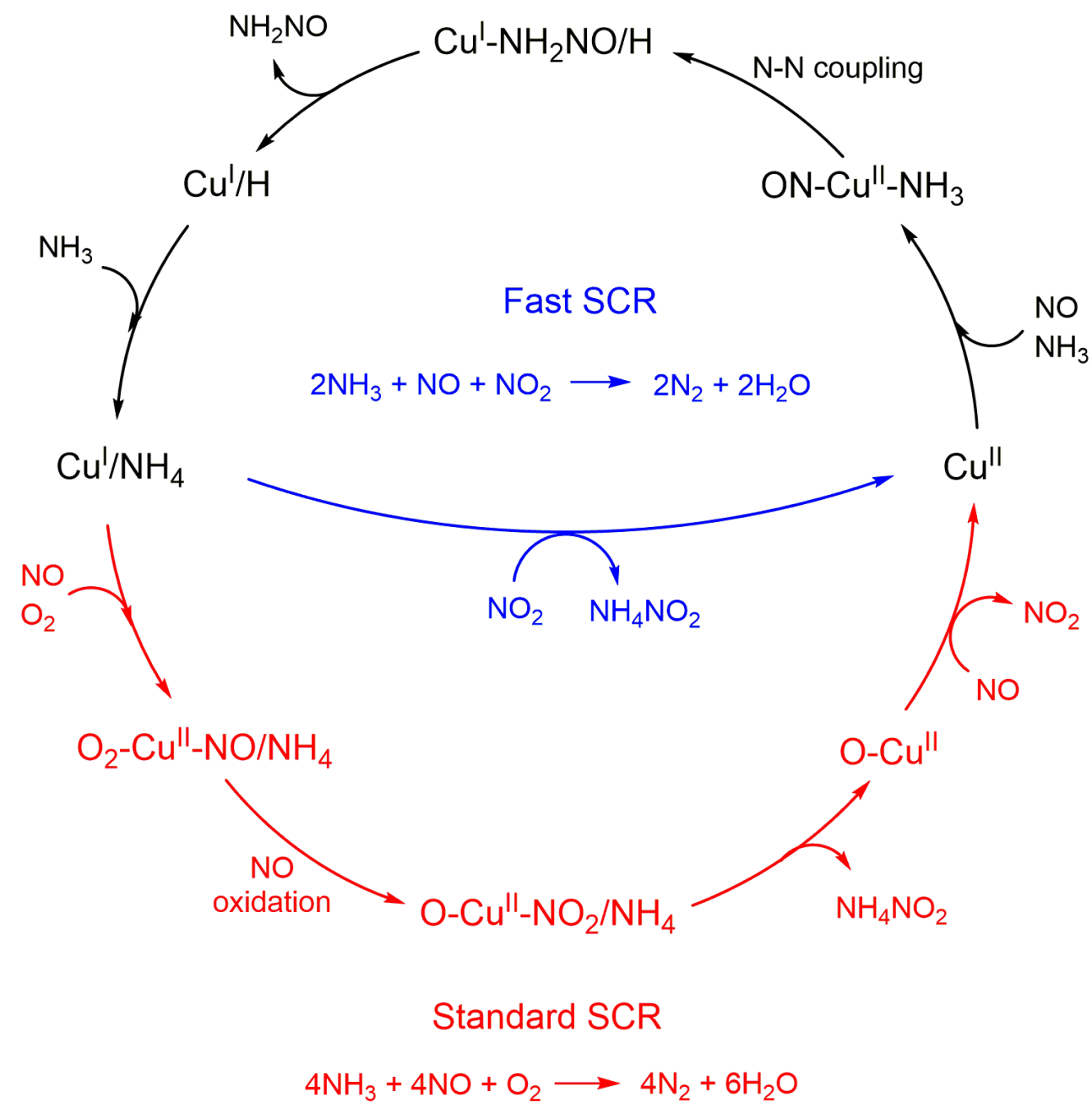

Figure 7: Schematic illustration of the mechanism of fast and standard $\mathrm{NH}_{3}-\mathrm{SCR}$ over $\mathrm{Cu}-$ SAPO-34. It should be noted that $\mathrm{NH}_{4} \mathrm{NO}_{2}$ and $\mathrm{NH}_{2} \mathrm{NO}$ will decompose to $\mathrm{N}_{2}$ and $\mathrm{H}_{2} \mathrm{O}$ stoichiometrically (equation 7 and scheme in Fig. 6), and it is not showed in the figure for clarity.

$\mathrm{NH}_{3}$ to produce $\mathrm{NH}_{4} \mathrm{NO}_{2}$, leaving on $\mathrm{O}$ atom on the $\mathrm{Cu}$ site. After that, the $\mathrm{O}$ atom will further oxidise $\mathrm{NO}$ to yield $\mathrm{NO}_{2}$. Next, the active site is restored to pure $\mathrm{Cu}^{2+}$ and react with remaining two $\mathrm{NH}_{3}$, one $\mathrm{NO}$ and $\mathrm{NO}_{2}$ to form one $\mathrm{NH}_{4} \mathrm{NO}_{2}$ and $\mathrm{NH}_{2} \mathrm{NO}$. Finally, $\mathrm{NH}_{4} \mathrm{NO}_{2}$ and $\mathrm{NH}_{2} \mathrm{NO}$ decompose into $\mathrm{N}_{2}$ and $\mathrm{H}_{2} \mathrm{O}$. Among all these process, the effective free energy barrier of NO oxidation is the highest $(0.86 \mathrm{eV})$ and may thus be regarded as the rate-limiting step.

From the mechanism, we can notice that the standard SCR has to go through both NO activation (coupling with $\mathrm{NH}_{3}$ ) and $\mathrm{NO}$ oxidation processes, which are closely related with 
each other to ensure the whole reactions to be completed. Firstly, $\mathrm{NO}$ and $\mathrm{NH}_{3}$ will couple with the assistance of $\mathrm{O}$ in the framework to produce $\mathrm{NH}_{2} \mathrm{NO}$ and reduce $\mathrm{Cu}^{2+}$ to $\mathrm{Cu}^{+}$. Then, NO will be oxidised over $\mathrm{Cu}^{+}$site to further form $\mathrm{NH}_{4} \mathrm{NO}_{2}$; however, in addition to producing $\mathrm{NO}_{2}$, a more vital role of $\mathrm{NO}$ oxidation is to regenerate $\mathrm{Cu}^{2+}$ site to keep reactions on going. Without it, the zeolite will be soon saturated with reduced $\mathrm{Cu}^{+}$species, and the overall reaction will be stopped. With these two essential processes, the standard SCR can proceed continuously, producing $\mathrm{N}_{2}$ by the stoichiometric decomposition of $\mathrm{NH}_{4} \mathrm{NO}_{2}$ and $\mathrm{NH}_{2} \mathrm{NO}$.

Comparing with $\mathrm{Cu}-\mathrm{SSZ}-13$, which is currently in commercial use and attracted most attentions in the past decades, our work represents one of few DFT studies on NH3-SCR mechanism over Cu-SAPO-34, well extending beyond what have been published on SSZ-13. The location of active $\mathrm{Cu}$ site, the redox cycle of $\mathrm{Cu}^{+}$and $\mathrm{Cu}^{2+}$, and the coupling of $\mathrm{N}-\mathrm{N}$ bond are quite similar on these two zeolites. Both $\mathrm{NH}_{3}$ and $\mathrm{NO}$ are required for $\mathrm{N}-\mathrm{N}$ coupling and $\mathrm{Cu}^{2+}$ would be reduced to $\mathrm{Cu}^{+}$to complete the reduction of the redox cycle, which is in agreement with experiments. ${ }^{11,28}$ Some notable differences, on the other hand, appear on the $\mathrm{NH}_{2} \mathrm{NO}$ decomposition and $\mathrm{NO}$ oxidation. Previous literatures suggested that the effect of Brønsted acid sites are rather limited. ${ }^{11,25,37}$ It is found that the SCR activity under $473 \mathrm{~K}$ is not dependent on the amount of Brønsted acid sites. Based on this experimental observation, the Brønsted acid site may not be a part of SCR process, and thus it can only influence SCR activity by altering the acidity of zeolite or interacting with neighbouring $\mathrm{Cu}$ site. Gao et al. ${ }^{17}$ pointed out that Brønsted acidity favors the standard $\mathrm{NH}_{3}-\mathrm{SCR}$ without being an essential ingredient of the active site. However, according to our results, Brønsted acid sites are necessary for $\mathrm{NH}_{2} \mathrm{NO}$ decomposition which is difficult to occur on $\mathrm{Cu}$ sites. Through a hydrogen push-pull mechanism, we showed that Brønsted acid sites could readily catalyse the decomposition of $\mathrm{NH}_{2} \mathrm{NO}$, also in agreement with some theoretical studies. ${ }^{6,35,36}$ The fact that the SCR activity does not depend on the Brønsted acid can be reconciled by realizing that there are usually more Brønsted acid sites than Lewis acid sites in zeolites; 
only a small portion of Brønsted acid sites would take part in the SCR while Lewis acid sites are saturated with the reaction. Therefore, the amount of Brønsted acid sites would not significantly influence the SCR activity.

The pathway of NO oxidation we presented in this contribution is also different from the literature works. Janssens et al. ${ }^{11}$ suggested that $\mathrm{NO}$ and $\mathrm{O}_{2}$ would react on the $\mathrm{Cu}^{+}$ site to form $\mathrm{Cu}^{2+} \mathrm{NO}_{3}{ }^{-}$, followed by the oxidation with another $\mathrm{NO}$ to produce $\mathrm{NO}_{2}$ and $\mathrm{Cu}^{2+} \mathrm{NO}_{2}{ }^{-}$. Our mechanism, on the other hand, do not include $\mathrm{NO}_{3}{ }^{-}$species in the NO oxidation since our DFT calculations showed that the free energy of $\mathrm{Cu}^{2+} \mathrm{NO}_{3}{ }^{-}$is rather high. However, both Janssens et al. and we agree that NO oxidation is the rate-limiting step, and all the elementary steps involved in the fast SCR are also parts of the standard SCR. It seems contradictory to the work of Tronconi et al., ${ }^{50,75}$ who observed that the rate of NO oxidation is much slower than SCR process. This puzzle can be understood from Fig. 7. We can see that the NO oxidation in SCR is part of the reaction cycle rather than a isolated step; the NO oxidation alone would be slow in zeolite since most $\mathrm{Cu}$ site in zeolites are $\mathrm{Cu}^{2+}$ without the SCR redox cycle, while NO oxidation is favoured only when the site is reduced to $\mathrm{Cu}^{+}{ }^{11}$

\section{General discussion of the zeolite chemistry}

In the last several decades, zeolites have been widely used in the fields of petrochemical industry, fine chemicals, and other heterogeneous reactions. ${ }^{79-82}$ As crystalline microporous materials, zeolites own many novel properties, such as species migration, ion exchange, and adsorption, which give us more efficient and cheap alternatives for some traditional catalytic reactions. The relation between the structure of $\mathrm{Cu}-\mathrm{SAPO}-34$ zeolites and activities of SCR process, however, has not been well understood. We therefore make a general discussion about its structure-activity relationship in this subsection, aiming to supplement current understandings on zeolite chemistry in general.

Starting from an isolated $\mathrm{Cu}^{2+}$ ion, the first step of SCR is the N-N coupling between 
$\mathrm{NO}$ and $\mathrm{NH}_{3}$ that goes through a small barrier $(0.28 \mathrm{eV})$. One question naturally arises here: why can NO be activated with such a low energy barrier? The origin lies in the special zeolite structure: in $\mathrm{Cu}-\mathrm{SAPO}-34$, the diameter of the six-membered ring is about $5 \sim 6$ $\AA$, and the structure of transition state (Fig. 3) fits such a ring well for the $\mathrm{N}-\mathrm{N}$ coupling; the whole molecule $\left(\mathrm{NH}_{2} \mathrm{NO}\right)$ bridges from the $\mathrm{Cu}$ ion to a $\mathrm{O}$ in the framework with a quite reasonable structure. One of $\mathrm{H}$ in the $\mathrm{NH}_{3}$ will interact with this $\mathrm{O}$ by the hydrogen bond, thus lowering the energy of the transition state. Meanwhile, the six-membered ring will also stretch to some extent to fit the structure of transition states owing to the flexibility of zeolite framework. Moreover, the weakened $\mathrm{N}-\mathrm{H}$ bond of the transition state also provides its $\mathrm{N}$ more space to couple with another $\mathrm{N}$. These features of zeolites may partly explain their good performance on $\mathrm{NH}_{3}$-SCR. Therefore, it was reasonable that the $\mathrm{N}-\mathrm{N}$ coupling process over Cu-SSZ-13 goes through a similar pathway since the geometrical structures of SAPO-34 and SSZ-13 are similar.

Equally important, deep insight into the redox cycle in zeolites has been achieved in this work. From Fig. 7, we can notice that the valence of $\mathrm{Cu}$ ion in $\mathrm{Cu}-\mathrm{NH}_{2} \mathrm{NO} / \mathrm{H}, \mathrm{Cu} / \mathrm{H}$, and $\mathrm{Cu} / \mathrm{NH}_{4}$ are +1 while for the rest species it is +2 (measured by the Bader charge analysis, details in Tab. S3). The redox cycle is very important in the whole SCR process especially for the standard SCR, since $\mathrm{Cu}^{2+}$ is not able to activate $\mathrm{O}_{2}$ molecules and the involvement of $\mathrm{Cu}^{+}$is crucial for $\mathrm{NO}$ oxidation according to the results in the last section. Aiming to clarify the role of zeolites in such a redox cycle, we calculated the valence number of each atom in the six-membered ring of $\mathrm{Cu}^{2+}$ and $\mathrm{Cu}^{+}$(Fig. 8ab). In Fig. 8b, one $\mathrm{H}$ remains on the O in the framework after the $\mathrm{N}-\mathrm{N}$ coupling, and most of its electron will transfer to the $\mathrm{Cu}$ through the framework, which eventually reduces $\mathrm{Cu}^{2+}$ into $\mathrm{Cu}^{+}$. Moreover, isosurfaces of charge density difference before and after $\mathrm{O}_{2}$ adsorption on these two $\mathrm{Cu}$ sites are presented in Fig. 8cd. It is clear from Fig. $8 \mathrm{c}$ that the bonding between $\mathrm{O}_{2}$ molecule and $\mathrm{Cu}^{2+}$ is very limited, because it is difficult for $\mathrm{Cu}^{2+}$ to donate electrons to $\mathrm{O}_{2}$, because it is on the highest oxidation state. On the other hand, we can see from Fig. $8 \mathrm{~d}$ that ceCu + has a considerable 
interaction with $\mathrm{O}_{2}$ by electron accumulation on $\mathrm{O}_{2}$ and depletion on $\mathrm{Cu}^{+}$. According to the Bader charge analysis, the valence of $\mathrm{Cu}$ and two $\mathrm{O}$ atoms before and after adsorption are $0.69,0,0$, and $1.01,-0.25,-0.1$, respectively, indicating that 0.35 electrons are donated from $\mathrm{Cu}$ ion and the framework to $\mathrm{O}_{2}$, and $\mathrm{Cu}^{+}$partly resumes to $\mathrm{Cu}^{2+}$. Therefore, the $\mathrm{O}-\mathrm{O}$ bond in the $\mathrm{O}_{2}$ molecule is activated upon adsorption on $\mathrm{Cu}^{+}$, leading to a stronger $\mathrm{O}_{2}$ adsorption energy and lower energy barrier for NO oxidation.

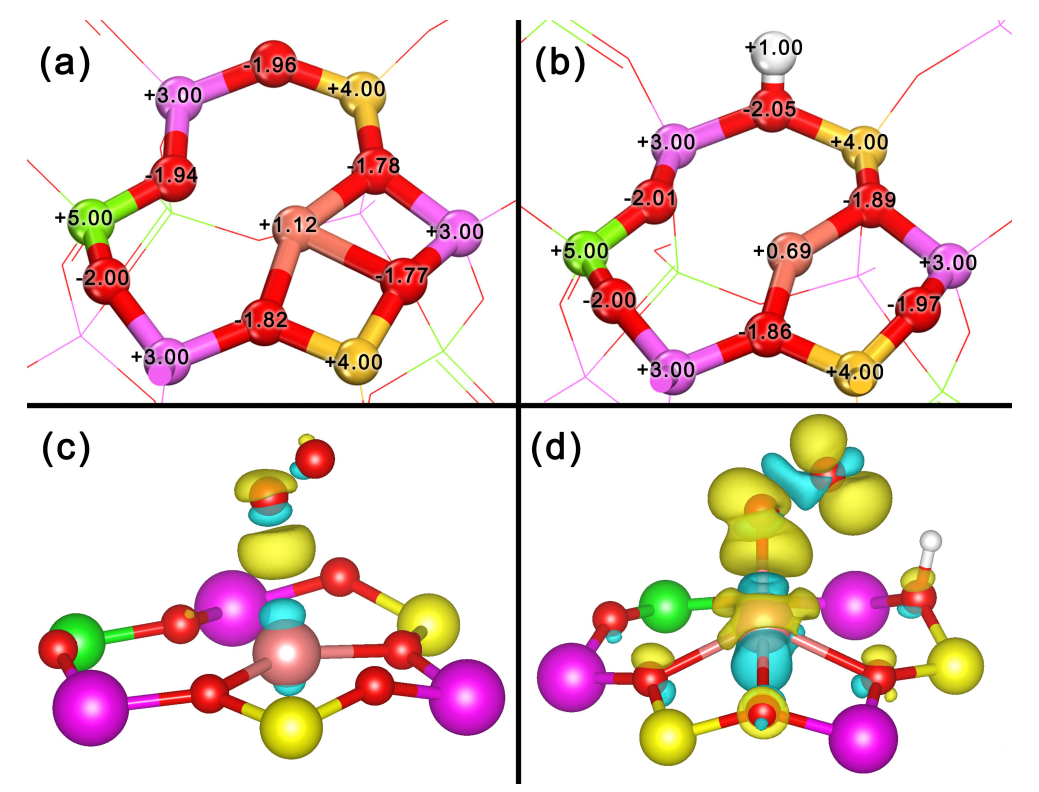

Figure 8: Bader charge of the six-membered ring loaded with $\mathrm{Cu}^{2+}$ (a) and $\mathrm{Cu}^{+}(\mathrm{b})$; isosurfaces (level: 0.0025$)$ of charge density difference before and after $\mathrm{O}_{2}$ adsorption on $\mathrm{Cu}^{2+}$ (c) and $\mathrm{Cu}^{+}(\mathrm{d})$. Yellow indicates the electronic accumulation and light blue for depletion.

In addition to the Lewis acid site ( $\mathrm{Cu}$ ion), the last part of SCR process, the decomposition of $\mathrm{NH}_{2} \mathrm{NO}$, occurs on the Brønsted acid site with moderate energy barriers. Our calculations show that the adsorption free energy of $\mathrm{NH}_{2} \mathrm{NO}$ on the $\mathrm{Cu}$ site is close to zero; therefore, it could readily transfer to Brønsted acid sites in the cage. $\mathrm{NH}_{2} \mathrm{NO}$ is difficult to decompose on the Lewis acid sites due to a large intra-molecular proton transfer barrier, while the Brønsted acid sites can facilitate this process by a hydrogen push-pull mechanism. It means that Brønsted acid and Lewis acid sites collectively catalyse the reaction, and such a "multi-site" concept of catalysis is receiving increasingly attention in recent years. ${ }^{64,83}$

Finally, both similarities and differences can be found comparing the SCR activity on 
traditional metal oxide catalysts with zeolites. In metal oxides (e.g. $\mathrm{MnO}_{2}$ and $\mathrm{V}_{2} \mathrm{O}_{5}$ ), it is possible for $\mathrm{NH}_{3}$ to donate one $\mathrm{H}$ to surface $\mathrm{O}$ with a reasonable barrier, ${ }^{84,85}$ but such a pathway is not practical on zeolites since the ability of zeolite framework to accept $\mathrm{H}$ is inferior to that of oxides. On CHA-type zeolites, the six-membered ring serves as a bridge to facilitate the coupling of $\mathrm{N}-\mathrm{N}$ bond as well as the breaking of $\mathrm{N}-\mathrm{H}$ bond in $\mathrm{NH}_{3}$. On the other hand, there is a similar concept of redox cycle of active site and interplay between the Brønsted acid and Lewis acid sites on traditional catalysts. Taking $\mathrm{V}_{2} \mathrm{O}_{5}$ as an example, $\mathrm{V}^{5+}$, which serves as Lewis acid site, will be reduced to $\mathrm{V}^{4+}$ when $\mathrm{NO}$ react $\mathrm{NH}_{3}$ to produce $\mathrm{N}_{2}$ and $\mathrm{H}_{2} \mathrm{O}$; it then resumes to $\mathrm{V}^{5+}$ during $\mathrm{NO}$ oxidation. The Brønsted acid site (H) over metal oxides can also facilitate $\mathrm{NH}_{2} \mathrm{NO}$ decomposition process.

\section{Conclusion}

In this work, a comprehensive investigation of $\mathrm{NH}_{3}$-SCR process over $\mathrm{Cu}-\mathrm{SAPO}-34$ zeolites was carried out by virtue of periodic DFT calculations using hybrid functional. Van der Waals (vdW) interactions were also considered throughout the calculation, the main conclusions of which are the following:

(i) A detailed step-by-step $\mathrm{NH}_{3}$-SCR mechanism over $\mathrm{Cu}-\mathrm{SAPO}-34$ was obtained with moderate energy barriers and reasonable intermediate structures.

(ii) A NO-assisted $\mathrm{N}-\mathrm{H}$ bond breaking mechanism of $\mathrm{NH}_{3}$ was determined to account for the $\mathrm{N}-\mathrm{N}$ formation between $\mathrm{NO}$ and $\mathrm{NH}_{3}$. The $\mathrm{NO}$ is activated by binding with $\mathrm{N}$ in $\mathrm{NH}_{3}$ to form $\mathrm{NH}_{2} \mathrm{NO}$ while one of its $\mathrm{N}-\mathrm{H}$ bond is weakened. The extra $\mathrm{H}$ would remain at the six-membered ring of the zeolite, reducing the original $\mathrm{Cu}^{2+}$ into $\mathrm{Cu}^{+}$.

(iii) The NO oxidation by $\mathrm{O}_{2}$ was shown to occur on reduced $\mathrm{Cu}$ site $\left(\mathrm{Cu}^{+}\right)$, and the $\mathrm{Cu}^{+}$ will resume to $\mathrm{Cu}^{2+}$ after oxidation, completing the $\mathrm{Cu}^{2+} / \mathrm{Cu}^{+}$redox cycle.

(iv) A detailed decomposition mechanism of $\mathrm{NH}_{2} \mathrm{NO}$ in the Brønsted acid site was iden- 
tified, confirming not only its feasibility, but also a collective efforts of Brønsted acid and Lewis acid $\left(\mathrm{Cu}^{2+}\right)$ sites in catalysing $\mathrm{NH}_{3}$-SCR over $\mathrm{Cu}-\mathrm{SAPO}-34$ zeolites.

The relation of above conclusions to the structural and electronic properties of zeolites, including their special six-membered ring structure, influence of the framework $\mathrm{H}$ on the valence of loaded metal ion, collective efforts by Brønsted acid and Lewis acid sites, are discussed and compared with previous literatures. These features may be extended to other catalytic reactions over zeolites and would supplement current understandings on not only SCR over Cu-CHA but also on general zeolite chemistry.

\section{Acknowledgement}

This project is supported by National Key Basic Research Program of China (2013CB933201), National Natural Science Foundation of China (21303052, 21333003, 21622305), Shanghai Rising-Star Program (14QA1401100), Chen Guang project (13CG24), Young Elite Scientist Sponsorship Program by CAST, Fundamental Research Funds for the Central Universities and Special Program for Applied Research on Super Computation of the NSFC-Guangdong Joint Fund (the second phase). The authors gratefully acknowledge UK's national high performance computing service ARCHER (for which access was obtained via the UKCP consortium) for computing time. Y.M. thanks the Queen's University of Belfast and Chinese Scholarship Council for a joint scholarship.

\section{Supporting Information Available}

Details of additional notes, structures, and energies mentioned in the paper.

This material is available free of charge via the Internet at http://pubs.acs.org/. 


\section{References}

(1) Li, J. H.; Chang, H. Z.; Ma, L.; Hao, J. M.; Yang, R. T. Catal. Today 2011, 175, 147-156.

(2) Liu, F.; Yu, Y.; He, H. Chem. Commun. 2014, 50, 8445-8463.

(3) Mao, Y.; Wang, H.-F.; Hu, P. Int. J. Quantum Chem. 2015, 115, 618-630.

(4) Beale, A. M.; Gao, F.; Lezcano-Gonzalez, I.; Peden, C. H. F.; Szanyi, J. Chem. Soc. Rev. 2015, 44, 7371-7405.

(5) Koebel, M.; Elsener, M.; Kleemann, M. Catal. Today 2000, 59, 335-345.

(6) Li, J.; Li, S. H. J. Phys. Chem. C 2008, 112, 16938-16944.

(7) Bauerle, G. L.; Wu, S. C.; Nobe, K. Ind. Eng. Chem. Prod. R \& D 1978, 17, 117-122.

(8) Liu, Z.; Zhang, S.; Li, J.; Zhu, J.; Ma, L. Appl. Catal. B-Environ. 2014, 158-159, 11-19.

(9) Beale, A. M.; Lezcano-Gonzalez, I.; Maunula, T.; Palgrave, R. G. Catal. Struct. React. $2014,1,25-34$.

(10) Brandenberger, S.; Krocher, O.; Tissler, A.; Althoff, R. Catal. Rev. Sci. Eng. 2008, 50, $492-531$.

(11) Janssens, T. V. W.; Falsig, H.; Lundegaard, L. F.; VennestrÃ̈̈m, P. N. R.; Rasmussen, S. B.; Moses, P.; Giordanino, F.; Borfecchia, E.; Lomachenko, K. A.; Lamberti, C. et al. ACS Catal. 2015, 5, 2832-2845.

(12) Paolucci, C.; Parekh, A. A.; Khurana, I.; Di Iorio, J. R.; Li, H.; Albarracin Caballero, J. D.; Shih, A. J.; Anggara, T.; Delgass, W. N.; Miller, J. T. et al. J. Am. Chem. Soc. 2016, 138, 6028-6048. 
(13) Nova, I.; Tronconi, E. Urea-SCR Technology for deNOx After Treatment of Diesel Exhausts; Springer-Verlag: New York, 2014.

(14) Kwak, J. H.; Tonkyn, R. G.; Kim, D. H.; Szanyi, J.; Peden, C. H. F. J. Catal. 2010, 275, 187-190.

(15) Ma, L.; Cheng, Y. S.; Cavataio, G.; McCabe, R. W.; Fu, L. X.; Li, J. H. Appl. Catal. B-Environ. 2014, 156, 428-437.

(16) Lezcano-Gonzalez, I.; Wragg, D. S.; Slawinski, W. A.; Hemelsoet, K.; Deyne, A.; Waroquier, M.; Speybroeck, V.; Beale, A. M. J. Phys. Chem. C 2015, 119, 24393-24403.

(17) Gao, F.; Washton, N. M.; Wang, Y.; KollÂąr, M.; Szanyi, J.; Peden, C. H. F. J. Catal. 2015, 331, 25-38.

(18) Andersen, C. W.; Bremholm, M.; Vennestrom, P. N. R.; Blichfeld, A. B.; Lundegaard, L. F.; Iversen, B. B. IUCrJ 2014, 1, 382-386.

(19) Deka, U.; Lezcano-Gonzalez, I.; Warrender, S. J.; Picone, A. L.; Wright, P. A.; Weckhuysen, B. M.; Beale, A. M. Micropor. Mesopor. Mat. 2013, 166, 144-152.

(20) Gao, F.; Walter, E. D.; Karp, E. M.; Luo, J.; Tonkyn, R. G.; Kwak, J. H.; Szanyi, J.; Peden, C. H. F. J. Catal. 2013, 300, 20-29.

(21) Wang, D.; Zhang, L.; Li, J. H.; Kamasamudram, K.; Epling, W. S. Catal. Today 2014, 231, 64-74.

(22) Yu, T.; Wang, J.; Shen, M. Q.; Li, W. Catal. Sci. Technol. 2013, 3, 3234-3241.

(23) McEwen, J. S.; Anggara, T.; Schneider, W. F.; Kispersky, V. F.; Miller, J. T.; Delgass, W. N.; Ribeiro, F. H. Catal. Today 2012, 184, 129-144.

(24) Goltl, F.; Bulo, R. E.; Hafner, J.; Sautet, P. J. Phys. Chem. Lett. 2013, 4, 2244-2249. 
(25) Bates, S. A.; Verma, A. A.; Paolucci, C.; Parekh, A. A.; Anggara, T.; Yezerets, A.; Schneider, W. F.; Miller, J. T.; Delgass, W. N.; Ribeiro, F. H. J. Catal. 2014, 312, $87-97$.

(26) Borfecchia, E.; Lomachenko, K. A.; Giordanino, F.; Falsig, H.; Beato, P.; Soldatov, A. V.; Bordiga, S.; Lamberti, C. Chem. Sci. 2015, 6, 548-563.

(27) Goltl, F.; Sautet, P.; Hermans, I. Catal. Today 2016, 267, 41-46.

(28) Paolucci, C.; Verma, A. A.; Bates, S. A.; Kispersky, V. F.; Miller, J. T.; Gounder, R.; Delgass, W. N.; Ribeiro, F. H.; Schneider, W. F. Angew. Chem. Int. Ed. 2014, 53, $11828-33$.

(29) Korhonen, S. T.; Fickel, D. W.; Lobo, R. F.; Weckhuysen, B. M.; Beale, A. M. Chem. Commun. 2011, 47, 800-802.

(30) Beale, A. M.; Lezcano-Gonzalez, I.; Slawinksi, W. A.; Wragg, D. S. Chem. Comm. 2016, 52, 6170-6173.

(31) Fickel, D. W.; Lobo, R. F. J. Phys. Chem. C 2010, 114, 1633-1640.

(32) Deka, U.; Juhin, A.; Eilertsen, E. A.; Emerich, H.; Green, M. A.; Korhonen, S. T.; Weckhuysen, B. M.; Beale, A. M. J. Phys. Chem. C 2012, 116, 4809-4818.

(33) Gao, F.; Walter, E. D.; Kollar, M.; Wang, Y.; Szanyi, J.; Peden, C. H. F. J. Catal. 2014, 319, 1-14.

(34) Xue, J.; Wang, X.; Qi, G.; Wang, J.; Shen, M.; Li, W. J. Catal. 2013, 297, 56-64.

(35) Bruggemann, T. C.; Keil, F. J. J. Phys. Chem. C 2008, 112, 17378-17387.

(36) Li, J.; Li, S. Phys. Chem. Chem. Phys. 2007, 9, 3304-11.

(37) Bates, S. A.; Delgass, W. N.; Ribeiro, F. H.; Miller, J. T.; Gounder, R. J. Catal. 2014, 312, 26-36. 
(38) Szanyi, J.; Kwak, J. H.; Zhu, H.; Peden, C. H. F. Phys. Chem. Chem. Phys. 2013, 15, $2368-2380$.

(39) Giordanino, F.; Borfecchia, E.; Lomachenko, K. A.; Lazzarini, A.; Agostini, G.; Gallo, E.; Soldatov, A. V.; Beato, P.; Bordiga, S.; Lamberti, C. J. Phys. Chem. Lett. 2014, 5, 1552-1559.

(40) Uzunova, E. L.; Mikosch, H.; St. Nikolov, G. Int. J. Quantum Chem. 2013, 113, 723728.

(41) Fulton, J. L.; Hoffmann, M. M.; Darab, J. G.; Palmer, B. J.; Stern, E. A. J. Phys. Chem. A 2000, 104, 11651-11663.

(42) Kwak, J. H.; Varga, T.; Peden, C. H. F.; Gao, F.; Hanson, J. C.; Szanyi, J. J. Catal. 2014, 314, 83-93.

(43) Goltl, F.; Hafner, J. J. Chem. Phys. 2012, 136, 064501.

(44) Kispersky, V. F.; Kropf, A. J.; Ribeiro, F. H.; Miller, J. T. Phys. Chem. Chem. Phys. 2012, 14, 2229-2238.

(45) Gunter, T.; Carvalho, H. W. P.; Doronkin, D. E.; Sheppard, T.; Glatzel, P.; Atkins, A. J.; Rudolph, J.; Jacob, C. R.; Casapu, M.; Grunwaldt, J.-D. Chem. Comm. 2015, 51, 9227-9230.

(46) Gao, F.; Kwak, J. H.; Szanyi, J.; Peden, C. H. F. Top. Catal. 2013, 56, 1441-1459.

(47) Yu, T.; Hao, T.; Fan, D.; Wang, J.; Shen, M.; Li, W. The Journal of Physical Chemistry C 2014, 118, 6565-6575.

(48) Doronkin, D. E.; Casapu, M.; GÃijnter, T.; MÃijller, O.; Frahm, R.; Grunwaldt, J.-D. The Journal of Physical Chemistry C 2014, 118, 10204-10212. 
(49) Chen, H.-Y.; Sun, Q.; Wen, B.; Yeom, Y.-H.; Weitz, E.; Sachtler, W. M. H. Catal. Today 2004, 96, 1-10.

(50) Ruggeri, M. P.; Nova, I.; Tronconi, E. Top. Catal. 2013, 56, 109-113.

(51) Bruggemann, T. C.; Keil, F. J. J. Phys. Chem. C 2011, 115, 23854-23870.

(52) Krukau, A. V.; Vydrov, O. A.; Izmaylov, A. F.; Scuseria, G. E. The Journal of Chemical Physics 2006, 125, 224106.

(53) Heyd, J.; Scuseria, G. E. The Journal of Chemical Physics 2004, 121, 1187-1192.

(54) Heyd, J.; Scuseria, G. E.; Ernzerhof, M. The Journal of Chemical Physics 2003, 118, $8207-8215$.

(55) Kresse, G.; Furthmüller, J. Comp. Mater. Sci. 1996, 6, 15-50.

(56) Kresse, G.; Hafner, J. Phys. Rev. B 1994, 49, 14251-14269.

(57) Grimme, S.; Antony, J.; Ehrlich, S.; Krieg, H. J. Chem. Phys. 2010, 132, 154104.

(58) Blöchl, P. E.; Jepsen, O.; Andersen, O. K. Phys. Rev. B 1994, 49, 16223-16233.

(59) Kresse, G.; Joubert, D. Phys. Rev. B 1999, 59, 1758-1775.

(60) Liu, Z.-P.; Hu, P. J. Am. Chem. Soc. 2003, 125, 1958-1967.

(61) Alavi, A.; Hu, P.; Deutsch, T.; Silvestrelli, P. L.; Hutter, J. Phys. Rev. Lett. 1998, 80, $3650-3653$.

(62) Perdew, J. P.; Burke, K.; Ernzerhof, M. Phys. Rev. Lett. 1996, 77, 3865-3868.

(63) Wang, Z.; Cao, X. M.; Zhu, J.; Hu, P. J. Catal. 2014, 311, 469-480.

(64) Wang, Z.; Wang, H.-F.; Hu, P. Chem. Sci. 2015, 6, 5703-5711. 
(65) Lok, B. M.; Messina, C. A.; Patton, R. L.; Gajek, R. T.; Cannan, T. R.; Flanigen, E. M. J. Am. Chem. Soc. 1984, 106, 6092-6093.

(66) Petitto, C.; Delahay, G. Chem. Eng. J. 2015, 264, 404-410.

(67) Wang, J.; Yu, T.; Wang, X. Q.; Qi, G. S.; Xue, J. J.; Shen, M. Q.; Li, W. Appl. Catal. B-Environ. 2012, 127, 137-147.

(68) Uzunova, E. L.; Mikosch, H.; Hafner, J. J. Phys. Chem. C 2008, 112, 2632-2639.

(69) Smith, L.; Cheetham, A. K.; Morris, R. E.; Marchese, L.; Thomas, J. M.; Wright, P. A.; Chen, J. Science 1996, 271, 799-802.

(70) Termath, V.; Haase, F.; Sauer, J.; Hutter, J.; Parrinello, M. J. Am. Chem. Soc. 1998, $120,8512-8516$.

(71) Uzunova, E. L.; Goltl, F.; Kresse, G.; Hafner, J. J. Phys. Chem. C 2009, 113, 52745291.

(72) Uzunova, E. L.; Mikosch, H.; Hafner, J. J. Mol. Struc.-Theochem 2009, 912, 88-94.

(73) Smith, L.; Cheetham, A.; Marchese, L.; Thomas, J.; Wright, P.; Chen, J.; Gianotti, E. Catal. Lett. 1996, 41, 13-16.

(74) Shi, L.; Yu, T.; Wang, X. Q.; Wang, J.; Shen, M. Q. Acta Phys-Chim. Sin. 2013, 29, $1550-1557$.

(75) Ruggeri, M. P.; Selleri, T.; Colombo, M.; Nova, I.; Tronconi, E. J. Catal. 2014, 311, $266-270$.

(76) Verma, A. A.; Bates, S. A.; Anggara, T.; Paolucci, C.; Parekh, A. A.; Kamasamudram, K.; Yezerets, A.; Miller, J. T.; Delgass, W. N.; Schneider, W. F. et al. J. Catal. 2014, 312, 179-190.

(77) Anstrom, M.; Topsøe, N.-Y.; Dumesic, J. A. J. Catal. 2003, 213, 115-125. 
(78) Cheng, J.; Hu, P.; Ellis, P.; French, S.; Kelly, G.; Lok, C. M. J. Phys. Chem. C 2008, 112, 1308-1311.

(79) Weckhuysen, B. M.; Yu, J. Chem. Soc. Rev. 2015, 44, 7022-7024.

(80) Li, Y.; Yu, J. Chem. Rev. 2014, 114, 7268-7316.

(81) Van Speybroeck, V.; Hemelsoet, K.; Joos, L.; Waroquier, M.; Bell, R. G.; Catlow, C. R. A. Chem. Soc. Rev. 2015, 44, 7044-7111.

(82) Peng, C.; Wang, H. F.; Hu, P. Phys. Chem. Chem. Phys. 2016, 18, 14495-14502.

(83) Burch, R.; Paun, C.; Cao, X. M.; Crawford, P.; Goodrich, P.; Hardacre, C.; Hu, P.; McLaughlin, L.; Sa, J.; Thompson, J. M. J. Catal. 2011, 283, 89-97.

(84) Janssen, F. J. J. G.; Van den Kerkhof, F. M. G.; Bosch, H.; Ross, J. R. H. J. Phys. Chem. 1987, 91, 6633-6638.

(85) Soyer, S.; Uzun, A.; Senkan, S.; Onal, I. Catal. Today 2006, 118, 268-278. 


\section{Graphical TOC Entry}

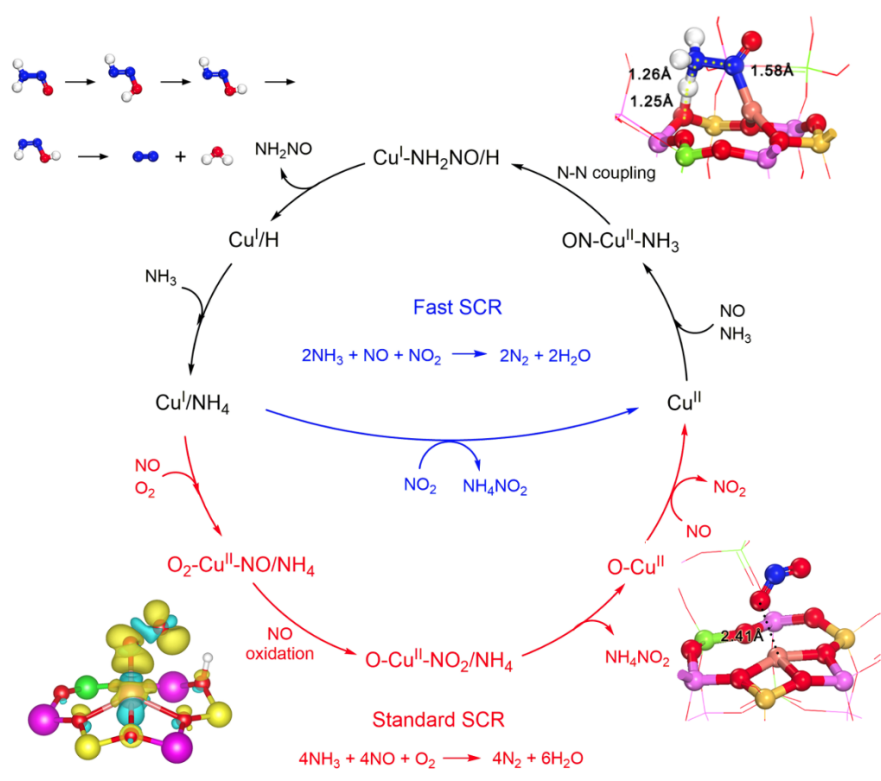

1

2

5

6

7

8

9

10

11

12

13

14

16

17

18

19

20

21

22

23

24

25

26

27

28

29

30

31

32

33

34

35

36

37

38

39

40

41

42

43

44

45

46

47

48

49

50

51

52

53

54

55

56

57

58

59

60 


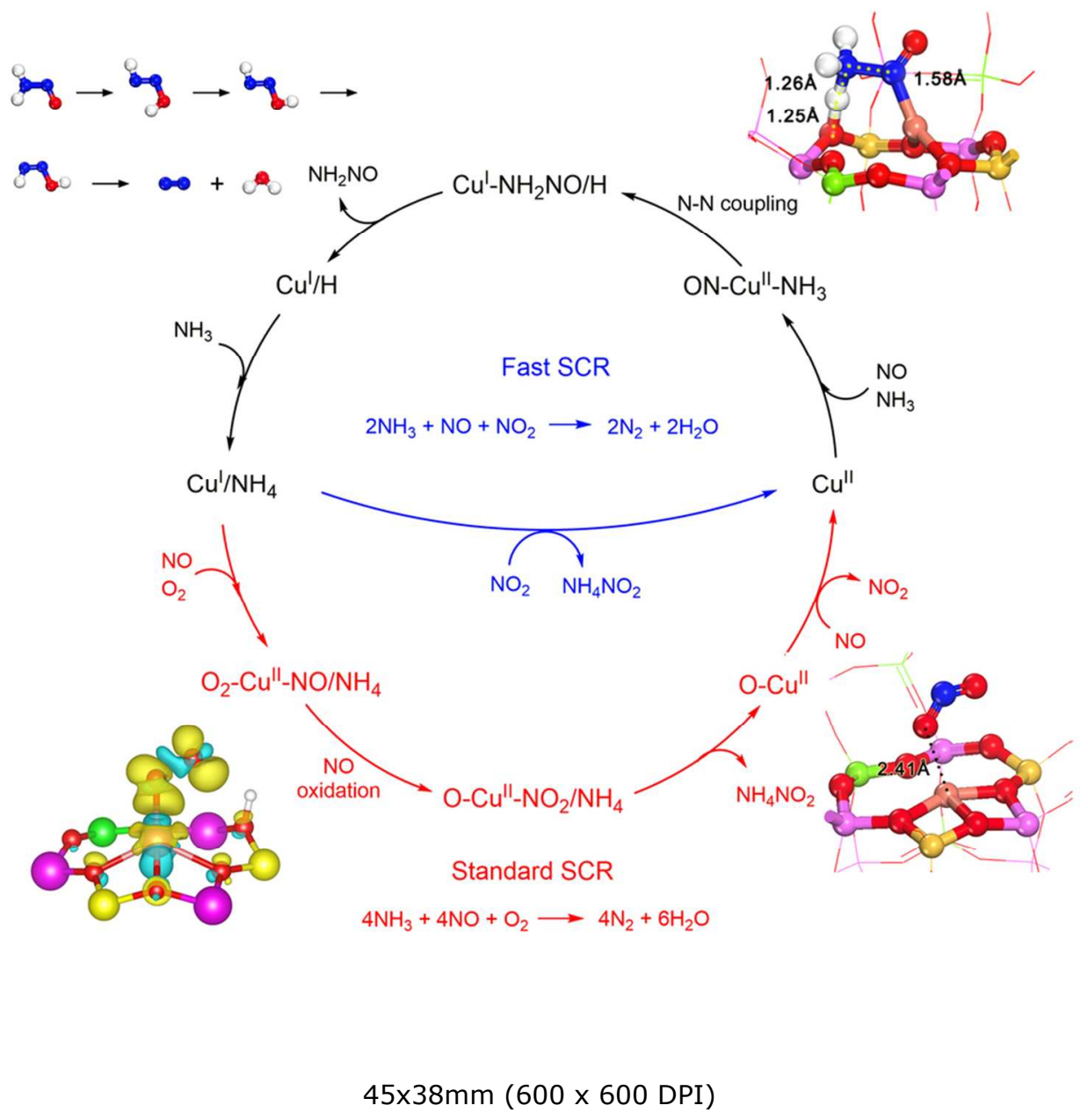

